NBER WORKING PAPER SERIES

\title{
INTERNATIONALIZATION AND STOCK MARKET LIQUIDITY
}

\author{
Ross Levine \\ Sergio Schmukler \\ Working Paper 11894 \\ http://www.nber.org/papers/w11894 \\ NATIONAL BUREAU OF ECONOMIC RESEARCH \\ 1050 Massachusetts Avenue \\ Cambridge, MA 02138 \\ December 2005
}

Levine: Brown University and the NBER (ross_levine@brown.edu). Schmukler: World Bank (sschmukler@worldbank.org). The paper was revised while Schmukler was visiting the IMF Research Department. We thank Tatiana Didier and Juan Carlos Gozzi Valdez for truly outstanding research assistance. We are grateful to Franklin Allen and Marco Pagano for very useful and detailed comments. We also received very helpful suggestions from Gordon Alexander, Luca Benzoni, Stijn Claessens, Peter Henry, Eduardo Loyo, Ugo Panizza, Valery Polknichenko, Helene Rey, Michael Schill, Frank Warnock, two anonymous referees, seminar participants at Dartmouth College, the Econometric Society Meetings (Chile), the NBER IASE Meeting in PUC-Rio (Brazil), the University of Minnesota, the University of Virginia (Darden School of Business), the University of Zurich, and the World Bank. For help with the data, we thank particularly Florencia Moizeszowicz and also Pamela Dottin, Monica Erpen, Dori Flanagan, Marina Halac, Angela Marshall, Konstantinos Tzioumis, Richard Webster-Smith, and Cheryl Workman. Levine is grateful for generous financial support from the BSI Gamma Foundation. Schmukler thanks the World Bank Latin American Regional Studies Program and Research Support Budget for ample financial support. The findings, interpretations, and conclusions expressed in this paper are entirely those of the authors and do not necessarily represent the views of the World Bank. The views expressed herein are those of the author(s) and do not necessarily reflect the views of the National Bureau of Economic Research.

(C2005 by Ross Levine and Sergio Schmukler. All rights reserved. Short sections of text, not to exceed two paragraphs, may be quoted without explicit permission provided that full credit, including $\odot$ notice, is given to the source. 
Internationalization and Stock Market Liquidity

Ross Levine and Sergio Schmukler

NBER Working Paper No. 11894

December 2005

JEL No. IG15, F36, F20

\begin{abstract}
$\underline{\text { ABSTRACT }}$
What is the impact of internationalization (firms raising capital and trading in international markets) on the liquidity of the remaining firms in domestic markets? To address this question, we assemble a panel database of nearly 2,900 firms from 45 emerging economies over the period 1989-2000, constructed from annual and daily data. First, we find evidence of migration. The domestic trading of firms that cross-list or issue depositary receipts in foreign public exchanges tends to decrease, while a significant proportion of their trading activity concentrates in international markets. Second, this migration is negatively related to the liquidity of the remaining firms in their home market through two separate channels. There are liquidity spillovers within markets, with aggregate domestic trading activity being positively associated with the liquidity of individual firms in the same market. Moreover, the proportion of trading abroad is negatively related to the liquidity of firms in the domestic market.

Ross Levine

Department of Economics

Brown University

64 Waterman Street

Providence, RI 02912

and NBER

ross_levine@brown.edu

Sergio Schmukler

World Bank

sschmukler@worldbank.org
\end{abstract}




\section{Introduction}

This paper analyzes the impact of firms from emerging economies that internationalize by issuing depositary receipts, cross-listing, or raising capital in international equity markets on the liquidity of the remaining firms in the domestic stock market. Although an extensive literature finds that internationalization helps these "international firms," researchers are only beginning to assess the ramifications of internationalization on "domestic firms," those firms that do not internationalize. ${ }^{1}$ Similarly, although emerging market policymakers increasingly express concerns that internationalization is hurting their domestic markets, surprisingly little research examines the impact of internationalization on domestic firms. ${ }^{2}$ To evaluate the cross-firm distributional effects of internationalization, we first examine the relation between internationalization and the trading of international firms by documenting what happens to a firm's trading activity and location of this trading after it internationalizes. We then study whether the trading activity of international firms is associated with the liquidity of domestic firms. Specifically, we examine whether there are market externalities: Is aggregate trading activity related to the liquidity of individual firms trading in the same market? We also test whether the location of trading activity of international firms affects the liquidity of domestic firms.

The literature provides conflicting predictions about the relation between internationalization and the liquidity of domestic firms. Consider first the two-part "migration and spillover" mechanism. "Migration" means that internationalization induces a shift in the trading of international firms out of

\footnotetext{
${ }^{1}$ Some examine the volume and liquidity of international firms in domestic markets, e.g., see Hargis (1998), Noronha et al. (1996), and Pulatkonak and Sofianos (1999). Others study the impact of internationalization on stock prices, e.g., see Alexander et al. (1988), Foerster and Karolyi (1999), and Miller (1999). Still others analyze asset size, growth, financing constraints, and the capital structure of firms, e.g., see Pagano et al. (2002), and Schmukler and Vesperoni (2006). See Karolyi (2006) for a review.

${ }^{2}$ For concerns that local markets are becoming illiquid due to internationalization, see Bovespa, (1996), Federation des Bourses de Valeurs (2000), Financial Times (1998), Latin Finance (1999, 2004); and The Economist (2000). To overcome the illiquidity of domestic markets policymakers are trying to come up with new solutions, like the creation of Novo Mercado in Brazil or the establishment of regional stock exchanges. See World Bank (2004).
} 
the domestic market and into international financial centers. This may occur because international markets have lower information and transaction costs (Chowdhry and Nanda, 1991; Lang et al., 2003), lower settlement risk (Velli, 1994), or more efficient risk pricing (Patro, 2000). "Spillover" means that the aggregate trading in a market is related to the liquidity of individual equities. Using data from the U.S., Chordia et al. (2000), Hasbrouck and Seppi (2001), and Coughernour and Saad (2004) find that liquidity is not simply an asset specific attribute; rather, an individual asset's liquidity co-moves with market liquidity. Beyond the possibility that common factors influence the liquidity of all firms in a market, there might be spillovers, whereby aggregate market activity influences the liquidity of individual firms. Spillovers could occur because of fixed costs associated with operating a market, like running brokerage firms and clearing and settling transactions. With spillovers, therefore, the migration of trading of international firms could increase the per-trade cost of domestic stock transactions and reduce the liquidity of domestic firms. Combined, migration and spillovers imply that cross-listing or issuing depositary receipts in public international stock markets hurts the liquidity of domestic firms.

The internationalization process might affect domestic markets beyond the migrationspillover channel. If it is more desirable to trade securities in major international financial centers and if investors are concerned about country-specific risk, then as some firms from a country internationalize, investors will shift their trading of that country's risk (as embodied in both international and domestic firms) out of domestic firms and into international firms in the international market. Indeed, there is evidence that U.S. investors prefer ADR over non-ADR stocks. ${ }^{3}$ The resultant shift in investor interest from domestic to international firms could hurt the liquidity of domestic firms beyond the effect through the reduction in domestic trading of international firms. At the firm level, internationalization might signal firm quality, which provides an additional mechanism

\footnotetext{
${ }^{3}$ See, Aggarwal et al. (2005), Bradshaw et al. (2004), and Edison and Warnock (2004).
} 
linking internationalization with a drop in domestic firm liquidity (Stulz, 1999). For example, internationalization might allow corporations to alleviate agency and informational asymmetry problems by "bonding" themselves into markets with greater disclosure requirements and stronger shareholder protection systems (Doidge et al., 2004; Gozzi et al., 2005; Reese and Weisbach, 2002; Siegel, 2005). Or, internationalization might reduce firms' cost of capital, by allowing them to overcome barriers between markets. From this perspective, internationalization provides a signal about firm quality, as the market is better able to distinguish "good" from "bad" firms (those that do not internationalize). ${ }^{4}$ By signaling firm quality, therefore, internationalization could hurt domestic firm liquidity.

Other papers, however, question the negative effects of internationalization on domestic liquidity. Hargis (2000) argues that cross-listings can transform a segmented equity market with low liquidity into an integrated market with high trading activity and liquidity. Alexander et al. (1987) and Domowitz et al. (1998) hold that internationalization stimulates domestic trading of international firms by increasing market integration. Moreover, Halling et al. (2005) argue that foreign trading of European firms declines after an initial increase, with liquidity returning to the domestic market (the "flow-back" effect). Also, if internationalization improves transparency, this could increase the domestic trading of international firms with positive spillover effects for the rest of the domestic market (Hargis and Ramanlal, 1998). It is also legitimate to question whether the finding of spillovers in the U.S. market generalizes to emerging stock exchanges and whether investors indeed prefer international to domestic firms. Thus, the linkages between internationalization and domestic market liquidity remain open empirical questions.

\footnotetext{
${ }^{4}$ Cantale (1996) and Fuerst (1998) present models with information asymmetry and establish a signaling equilibrium in which firms with better prospects are able to distinguish themselves from firms with lower future profitability by crosslisting in markets with stricter regulatory environments.
} 
To study the effects of internationalization, we assemble liquidity and trading indicators on nearly 2,900 firms from across 45 emerging market countries, covering the period 1989-2000. To measure trading activity, we use yearly turnover, which equals the value of a firm's transactions in a market divided by the firm's market capitalization. Turnover, and similar trade-based indicators, are frequently used to proxy for liquidity since (i) many countries do not have bid-ask spread information (especially time series data), ${ }^{5}$ (ii) it is difficult to collect the daily data for such a large panel of firms and countries, and (iii) past research identifies a strong link between turnover and firm performance, industrial expansion, and national growth. ${ }^{6}$ Nevertheless, since turnover does not directly measure trading costs or the price impact of transactions, we interpret turnover less as a precise measure of liquidity and more a as a general index of trading activity.

We also compute two indicators of liquidity, which are constructed from daily data. First, Amihud's (2002) illiquidity index, which equals the ratio of a stock's absolute returns to its value traded. Hasbrouck (2005) finds that, within the class of price-impact liquidity estimates, Amihud's (2002) illiquidity index is the most reliable proxy of trading costs. Second, we compute the proportion of days in a year when there are no changes in the price of a security. Since researchers have used liquidity measures based on this zero return index in recent studies (Lesmond, 2005; Lesmond et al., 1999), we use it to assess further the relation between internationalization and the liquidity of domestic firms.

\footnotetext{
${ }^{5}$ Also, some research argues that turnover can be a better proxy for liquidity than bid-ask spreads due to problems with measuring spreads. From a theoretical perspective, Amihud and Mendelson (1986) and Stoll (1978a) suggest a direct link between trading costs and trading volume and holding periods, respectively. Empirically, Atkins and Dyl (1997) and Stoll (1978b) confirm these predictions. Petersen and Fialkowski (1994) demonstrate the problems with computing accurate bid-ask spreads. Consequently, a large number papers use turnover and volume-based proxies of liquidity (e.g., Brennan et al., 1998; Datar et al., 1998; Haugen and Baker, 1996; Rouwenhorst, 1999).

${ }^{6}$ In terms of theory, Levine (1991) models the link between trading activity and both firm and national growth. Empirically, Beck and Levine (2002, 2004), Demirguc-Kunt and Maksimovic (1998), and Levine and Zervos (1998a) demonstrate the importance of turnover for explaining firm performance, industrial expansion, and economic growth.
} 
The results are broadly consistent with migration. When a firm cross-lists or issues depositary receipts in a public international exchange (e.g., the New York Stock Exchange, the London Stock Exchange, or NASDAQ), the domestic trading of its shares does not rise; rather, trading tends to migrate out of the domestic market and into the international market. However, firms that raise capital abroad without providing an easy vehicle for having their shares traded internationally, tend to experience an increase, not a decrease, in domestic trading activity. ${ }^{7}$ Furthermore, an important fraction of the total trading activity of firms that internationalize into a major public exchanges shifts abroad. On average, the percentage of trading in the domestic market falls to less that 60 percent after internationalization, with no significant flow-back effect in our sample.

The results are also consistent with spillovers: An individual stock's liquidity is closely related to aggregate trading activity in its market. The aggregate domestic turnover of international firms is positively associated with the turnover of domestic firms and negatively associated with both the Amihud and zero-return illiquidity indexes for domestic firms. Importantly, the positive relation between the liquidity of an individual domestic firm's stock and the aggregate trading of international firms in the domestic market holds when controlling for many time-varying country traits, country dummy variables, firm-specific characteristics, and the trading activity of that country's firms in international markets. Overall, the results are consistent with the migration and spillover view. Consistent with migration, cross-listing and issuing depositary receipts are associated with a drop in the turnover of international firms in their domestic markets and a shift of their trading abroad.

\footnotetext{
${ }^{7}$ For instance, firms that raise money through private placements in the U.S. by means of Rule $144 \mathrm{~A}$ can only trade among qualified institutional buyers on the PORTAL system. Firms that issue Level I ADRs trade on the over-the-counter market (OTC), which is not an organized market or exchange, but rather a network of securities dealers. These markets tend to provide less liquidity than public exchanges and therefore are less likely to generate migration of trading abroad. Therefore, we analyze these types of listings separately from cross-listings and capital raisings in major public exchanges and confirm that they have different effects on the domestic trading of international firms.
} 
Consistent with spillovers, the drop in the turnover of international firms in the domestic market is associated with a drop in the liquidity of domestic firms.

Another important finding of the paper is that internationalization is negatively associated with the liquidity of domestic firms beyond the migration-spillover channel. The fraction of total trading of a country's stocks (domestic and international) occurring in international markets is strongly, negatively related to the liquidity of domestic firms. Thus, not only is there a close connection between the aggregate domestic trading of international firms and a domestic firm's liquidity, but the share of trading occurring in international markets is independently and negatively linked to the liquidity of domestic firms.

Our research has both political economy and market microstructure implications. First, we find that international financial integration can have distributional implications. Firms that internationalize win: Internationalization boosts the total trading of international firms and they grow after internationalizing (Gozzi et al., 2005; Levine and Schmukler, 2003). But, domestic firms lose. The liquidity of their shares falls as other firms internationalize their trading activity. Thus, different firms are likely to have very different views about public policies related to internationalization. For instance, if there are high fixed costs to internationalizing and a country lowers legal barrier to internationalization, then its largest firms will tend to benefit relative to smaller firms for which the fixed costs represent a comparatively large barrier. Second, we find evidence of spillovers in stock markets around the world. This has potentially important implications for markets in an era of globalization. The prevalence of spillovers represents a powerful force encouraging liquidity to concentrate in a few major financial centers, domestically or abroad.

This paper's assessment of the impact of internationalization on the turnover and liquidity of domestic firms is related to a large literature on internationalization. First, research analyzes the 
impact of market integration on economic growth and investment (Bekaert et al., 2005; Henry, 2000; Levine and Zervos, 1998a,b). In this paper, we do not focus on financial integration broadly defined. Rather, we examine the impact of the decision of one set of firms to internationalize on the liquidity of those firms that do not internationalize. Second, as noted above, an extensive literature studies the effects of internationalization on international firms. Although we contribute to this work by assessing the connection between internationalization and the trading activity of international firms using our new database, the focus of our research is different. We concentrate on examining the link between internationalization and domestic firms.

Our work builds on two aggregate assessments of financial integration. Moel (2001) and Karolyi (2004) find a negative association between the fraction of a country's stocks that issue American Depositary Receipts (ADRs) and domestic market turnover. Our research makes several contributions. First, we use firm-level data, follow firms through time, and examine what happens to firms when they internationalize. Second, by using daily data for each firm, we compute commonly used proxies of liquidity and assess what happens to the liquidity of individual domestic firms as other firms internationalize. Third, we disentangle some of the channels through which internationalization can influence domestic stocks. Fourth, we substantially expand the country coverage. Our data cover 45 countries, while Karolyi (2004) and Moel (2001) study 12 countries and 28 countries respectively. Fifth, besides examining firms that internationalize by issuing depositary receipts in New York, we also examine (i) firms that issue depositary receipts in other countries and (ii) firms that cross-list and/or raise capital in New York and other financial centers. Sixth, we collect and incorporate time-varying data on the international trading activities of international firms. This allows us to identify more confidently the independent link between internationalization and domestic firm liquidity. 
The rest of the paper is organized as follows. Section 2 describes the data. Section 3 discusses the econometric methodology and presents the results. Section 4 concludes.

\section{Data}

To assess the connection between internationalization and the liquidity of domestic stocks, we construct a novel dataset using (i) firm-level data on trading and liquidity in the domestic market, (ii) data on the international activity of firms, including stock trading in international markets and dates of cross-listings, depositary receipts issuances, and capital raisings in international equity markets, (iii) firm-level data on firm attributes, and (iv) country-level data on turnover, macroeconomic, institutional, and financial conditions. Since the data come from various sources, we match the firmlevel variables on domestic stock market trading and liquidity, the firm-level balance sheet information, the data on the international equity market activities of each firm, and country-level characteristics.

As a measure of trading activity, which is also frequently used by researchers as a proxy for liquidity, we employ turnover, which equals a firm's value traded divided by its market capitalization. The data come from the Standard \& Poor's Emerging Markets Data Base (EMDB), formerly collected by the International Finance Corporation (IFC) of the World Bank. In crosschecking with country sources, the EMDB is very accurate. For Argentina, however, we discovered that the EMDB is inconsistent over time. Thus, unlike previous studies, we circumvent this problem by collecting the data directly from the Buenos Aires Stock Exchange. The EMDB provides data on domestic market capitalization and domestic value traded in current U.S. dollars by firm. Although the EMBD is one of the most comprehensive databases on firm-level trading of equities around the world, the EMDB focuses on emerging markets and does not include 100 percent of local firms (i.e., 
while varying by country, the EMDB typically covers about 70 percent of market capitalization). We have sufficient data to compute turnover for 2,875 firms.

We use daily data from Datastream to construct firm-level measures of annual liquidity for a broad cross-section of more than 1,000 firms, across 31 countries, over 12 years, totaling almost 1,600,000 firm-day observations. To measure firm-level liquidity, we construct Amihud's (2002) illiquidity index and the share of zero-return days. Section 3 defines these two illiquidity variables. After constructing these measures at a daily frequency, we aggregate and calculate the liquidity measures on a yearly basis to match the other data. We require that firms have a minimum of 50 daily observations within a year to compute the illiquidity measures. For the Amihud illiquidity ratio, we eliminate daily observations with absolute returns over 50 percent (following Lesmond, 2005) and remove the top and bottom one percent of the daily observations before computing the yearly measure to control for outliers. In calculating these illiquidity measures, we only use firms with data on turnover from the EMDB to keep results comparable across tables. Since data on returns is more easily available than data on trading activity, the number of daily observations used to compute the zero return measure is significantly higher than that used to calculate Amihud's illiquidity index, which requires information on value traded. We use nearly 1,600,000 daily observations to compute the zero return measure and over 1,050,000 daily observations to calculate Amihud's illiquidity index. Despite these differences, we were able to compute both annual liquidity measures for similar samples in terms of firm and time-series coverage.

Regarding the international equity market activities of firms, we collect more data than past studies to provide a more accurate categorization of the internationalization process. While most papers focus only on the ADR market and ignore internationalization in equity markets beyond the 
U.S., we consider a much broader array of international equity markets. The data for identifying and dating each firm's international activities come from different sources.

We start with data from the Bank of New York. Besides the bank's standard database (the Complete Depositary Receipt Directory) that contains information on current depositary receipt activities, the Bank of New York gave us access to their historical databases and reports on (i) depositary receipt program initiation dates, (ii) termination dates (if any), (iii) capital raisings, and (iv) trading activity. We complement these data with information from JP Morgan and Citigroup on ADR program initiation dates. The use of these additional sources helps us to cross-check the data, obtain missing information, and correct reporting errors. These data form a comprehensive database on ADR and Global Depositary Receipt (GDR) programs. The historical data start in January 1956, but the vast majority of programs begins after 1980 .

We augment this information on dating the initiation of international equity market activities with data from Euromoney, the London Stock Exchange (LSE), NASDAQ, and the New York Stock Exchange (NYSE). Euromoney provides the dates when firms raise equity capital in international markets, including cross-listings and issuance of global depositary receipts, which substantively enhances the accurate categorization of firms as international or domestic. The Euromoney database covers 8,795 cross-border equity issuance and cross-listing operations from 5,665 firms in 86 countries over the period January 1983 - April 2001. LSE, NASDAQ, and NYSE provide information on listing dates by foreign corporations.

Consistent with our objective of assembling a broad database on internationalization, we classify firms as international if they ever (i) issue depositary receipts, (ii) cross-list, or (iii) raise equity capital through private or public placements abroad. In the time-series dimension, a firm becomes international from the first time it issues a depositary receipt, cross-lists, or raises capital 
abroad. If it then de-lists, it is considered domestic again. Cross-listings, depositary receipts, and capital raisings on major public exchanges clearly involve ongoing trading of local firms in foreign countries. However, private capital raisings or cross-listings on over-the-counter (OTC) markets are different because they do not provide firms with an easy vehicle for having their shares traded abroad. Thus, while the issuance of depositary receipts and cross-listing on public exchanges may involve the two effects discussed in the Introduction (migration and spillovers), cross-listings on OTC markets and private capital raisings are less likely to generate migration. Therefore, we analyze these types of listings separately from cross-listings and capital raisings in public exchanges and confirm that they have a different relation with the domestic trading of international firms.

We use balance sheet information on each firm to control for firm-specific characteristics that may influence liquidity. For simplicity, in the results discussed below, we present the regressions controlling for firm size only, but the results are robust to controlling for other firm traits, e.g., sales growth and industry dummy variables. We obtain these data from the Worldscope database (Thomson Financial Company).

Regarding the country-level trading variables, we compute the aggregate domestic turnover of international and domestic firms from firm-level turnover data. Additionally, we compute the share of total trading taking place abroad. To measure total domestic trading, we use aggregate country-level data on value traded domestically from the EMDB. To calculate trading abroad, we use data on ADR trading. The dataset comes from the Bank of New York, providing the value traded in U.S. dollars at the firm level. We then aggregate these data to obtain country-level measures. Data from the LSE and the Frankfurt Stock Exchange (FSE) on the trading of depositary receipts and cross-listed firms are not available for our entire time span and, thus, are not included in our dataset. This underestimates 
the amount of trading abroad, but it is unlikely to systematically bias the results in any particular direction.

We include an assortment of country-level control variables. In particular, we use gross domestic product (GDP) per capita as a measure of countries' overall economic development. We also control for a country's stock market development by including the aggregate market capitalization as a percentage of GDP. We also estimated all the regressions including the law and order index as an independent variable to control for each country's legal and institutional environment. The law and order index rarely enters significantly because it is highly correlated with GDP per capita. Moreover, its inclusion does not affect any of the results reported below. Finally, since we analyze the impact of firms' decisions to internationalize, it is important to control for the stock market openness. Therefore, we include two alternative measures of stock market liberalization. The first one is a dummy variable which equals one after a country liberalizes its stock market, and zero otherwise. The data for dating the liberalization of stock markets come two sources: Bekaert et al. (2005), who present official liberalization dates, and Vinhas de Souza (2005), who constructs an index of the extent of stock market liberalization for Eastern European countries. We combine these two sources to get the widest possible coverage. The second stock market liberalization variable comes from Edison and Warnock (2003) and measures the degree of market integration by estimating the availability of a country's equities to foreigners. Note that the two liberalization variables differ in terms of country coverage. The Edison and Warnock measure covers 29 countries, while we have data to compute the stock market liberalization dummy for 39 of the countries included in our sample. As a robustness test, we estimated all the regressions including only firms from those countries that have data on both liberalization variables (27 countries) and obtained similar results. 
The final dataset covers the period 1989 to 2000, with over 9,000 firm-year observations, from 45 emerging economies (as classified by the EMDB). To control for the effects of possible outliers and data entry errors, we eliminate year observations when the dependent variable in a regression is more than three standard deviations away from the country mean. Appendix Table I lists the countries included in the study and the number of domestic and international firms per country used for the dependent variables and to compute the aggregate turnover measures. ${ }^{8}$ Appendix Table I also has summary statistics of the liquidity and trading variables. Appendix Table II provides additional information on the data sources.

\section{Methodology and Results}

This section examines the mechanisms through which firms that access international equity markets may affect the liquidity of firms that do not internationalize. The first part of this analysis involves testing for migration. Does the trading of a firm's stock migrate from the domestic to the international market after it internationalizes? Second, we test for how this migration might affect the liquidity of domestic firms. In particular, are the aggregate domestic trading activity of international firms and the share of trading abroad associated with the liquidity of individual stocks traded in the local market?

\subsection{MIGRATION}

\subsubsection{Migration: Cross-listing and Issuing Depositary Receipts in Public Exchanges}

We first examine what happens to the trading of a firm in the domestic market after it crosslists, issues a depositary receipt, or raises capital in an international public exchange. That is, we

\footnotetext{
${ }^{8}$ The difference in the number of firms used in the regressions and those used to calculate the aggregate measures is explained by the availability of data on the firm-level characteristics included in the regressions. Also, note that in the regressions of domestic firms we control for the average domestic turnover of firms that cross-listed or raised capital in major international exchanges, therefore only these international firms are used to compute the aggregate measures.
} 
examine only firms that create a mechanism to have their shares easily traded in a major international financial market. In this way, we restrict the sample to firms for which substantial migration is feasible. We estimate the following specification,

$$
T_{j, c, t}^{I}=\phi \times A_{j, c, t}+\alpha \times I D_{j, c, t}+\beta \times T_{c, t}^{D}+\gamma \times S T_{c, t}^{I}+\theta \times C_{c, t}+\delta_{1} \times n_{c}+\delta_{2} \times \tau_{t}+\varepsilon_{j, c, t}
$$

The regressions include country and year effects $\left(n_{c}\right.$ and $\tau_{t}$ respectively), though these are not reported in the tables. The regressions are estimated using Newey-West standard errors, reported in brackets. These standard errors are robust to heteroskedasticity and autocorrelation within firms. For robustness, the last column in each table also reports results estimated using standard errors clustered at the firm level.

$T_{j, c, t}^{I}$ is the logarithm of one plus the turnover ratio of international firm $\mathrm{j}$ from country c in year $\mathrm{t}$, where the turnover ratio equals the total value traded of firm $\mathrm{j}$ 's stock during year $\mathrm{t}$ divided by firm j's market capitalization. ${ }^{9}$ The superscript I designates that it is an international firm, which is a firm that issues a depositary receipt, cross-lists, or raises capital abroad at some point in the sample. As noted, we further restrict the sample in Table I to firms that cross-list or issue depositary receipts in public exchanges.

$A_{j, c, t}$ equals the logarithm of the total assets (in U.S. dollars) of firm $\mathrm{j}$ from country $\mathrm{c}$ in year t. Since research suggests that large, liquid firms tend to internationalize and since we want to capture the independent relation between internationalization and local activity, we control for firm size.

$I D_{j, c, t}$ is a dummy variable that equals zero if firm $\mathrm{j}$ from country c during year $\mathrm{t}$ has not yet internationalized. It equals one in the year the firm internationalizes and remains one thereafter unless

\footnotetext{
${ }^{9}$ We use this transformation because the total value traded is sometimes zero. Out of a total of more than 13,200 firmyear observations with data on turnover in our dataset, there are only 273 observation with total value traded equal to zero. We estimated all the regressions excluding those observations and obtained results similar to those reported below. We also estimated the regressions using the log of turnover and obtained similar results.
} 
the firm de-lists or ends its depositary receipt program. In defining the internationalization dummy, we use the firm's first internationalization activity. Thus, if a firm first issues a private placement abroad and later cross-lists in an international public exchange, this firm is not included in the Table I regressions. If the estimated coefficient on $I D_{j, c, t}$ is negative (i.e., if $\alpha<0$ ), then this indicates that when a firm internationalizes its turnover in the local market tends to fall.

$T_{c, t}^{D}$ is the logarithm of one plus the average turnover of domestic firms in country c during year t. Since we are testing whether the domestic trading activity of international firms changes when a firm internationalizes, we include the trading activity of other firms in the domestic market to control for the myriad of factors shaping aggregate domestic trading activity. This helps identify the connection between a firm's decision to internationalize and its domestic trading activity. Furthermore, including the average turnover of domestic firms provides information on the relation between the domestic activity of an individual firm, $T_{j, c, t}^{I}$, and aggregate market activity. In particular, a positive coefficient on the average turnover of domestic firms indicates that an individual firm's domestic trading activity is positively associated with aggregate trading in the market.

$S T_{c, t}^{I}$ equals the logarithm of one plus the value traded abroad of country c's international firms in year $\mathrm{t}$ divided by the total value traded in all markets of country c's international and domestic firms in year t. Including this variable provides an estimate of the relation between the degree to which a country's firms are traded abroad and the domestic trading of a firm's shares. This also provides greater power in assessing the independent relation between a firm's decision to internationalize and the trading of its shares on the local market.

$C_{c, t}$ is a set of time-varying country characteristics. We include two alternative measures of the openness of each country's stock exchanges. The stock market liberalization dummy equals zero 
before a country liberalizes and one after a country formally allows foreign investors to invest in domestic equities. The Edison and Warnock (2003) liberalization measure is the ratio of the market capitalization of the S\&P/IFC Investable Index over the total market capitalization of each country. ${ }^{10}$ This index provides a quantitative measure of the availability of the country's equities to foreigners. We include these indicators in the analyses to control for the possibility that national policies toward stock market liberalization will affect both domestic trading activity and internationalization decision. We also control for the country's level of economic and financial development as measured by GDP per capita and domestic stock market capitalization divided by the country's GDP. Thus, we want to evaluate the relation between a firm's decision to internationalize and its domestic trading activity while holding constant country and financial development.

The regressions reported in Table I and throughout the paper use unbalanced panels. Since the sample of firms for which we have complete sets of dependent and independent variables varies considerably over time, using a balanced sample reduces the overall number of observations significantly. Also, note that within each table the sample of firms varies across specifications, due to differences in the coverage of the country-level variables used in the regressions. We also estimated all the regressions holding the sample size constant across specifications and found similar results.

Table I provides evidence broadly consistent with migration. More specifically, firms that cross-list or issue depositary receipts tend to experience a drop in domestic trading activity. Across the different specifications, the internationalization dummy $\left(I D_{j, c, t}\right)$ enters with a negative coefficient. It enters significantly at the five percent level when using Newey-West standard errors that are robust to heteroskedasticity and autocorrelation at the firm level (regressions $1-5$ ) and at the

\footnotetext{
${ }^{10}$ Edison and Warnock (2003) calculate a smoothed measure that takes into account asymmetric shocks to investable and non-investable stocks, which would lead to changes in the ratio of market capitalization. They convert this variable into a capital control measure by taking one less the adjusted ratio. To be consistent with the stock market liberalization dummy, we converted their capital control measure into a liberalization index by subtracting one from it.
} 
ten percent level when using standard errors clustered at the firm level (regression 6). Critically, we find that a firm's domestic trading activity falls after it cross-lists or issues a depositary receipt in an international public exchange even when controlling for aggregate trading activity in the domestic market, liberalization of the domestic market, firm size, a number of country characteristics, as well as country and year dummy variables. The size of the coefficient in regression 5 of Table I indicates that the average firm experiences a fall of its domestic turnover of about 17 percent after cross-listing or issuing a depositary receipt in an international public exchange. To compute this, note that the dependent variable in these regressions is the logarithm of one plus the domestic turnover of international firms. Since the coefficient on the internationalization dummy is -0.06 , the estimated relation indicates that internationalization is associated with a six percent drop in one plus the domestic turnover of international firms. Given that the average domestic turnover for the sample of international firms included in regression 5 is 0.55 , this implies that internationalization into a public stock exchange is associated with a drop of 0.093 or 17 percent in the domestic turnover of the average firm.

Furthermore, Table I indicates a strong positive association between the average level of trading activity by domestic firms in the market and the domestic turnover of the firm that internationalizes. Average turnover of domestic firms enters positively and significantly in all of the regressions. This shows that the domestic trading activity of an individual firm is positively linked to aggregate trading in the market even after controlling for country and year effects, many time-varying country effects, as well as the size of the firm. The effect is also economically relevant. The size of the coefficient in regression 5 of Table I indicates that an individual international firm's domestic turnover tends to rise by more than five percent when there is an increase in the average turnover of domestic firms of 10 percent. To see this, note that the coefficient in regression 5 in Table I indicates 
that a rise in one plus the average turnover of domestic firms of five percent is associated with an increase in one plus the domestic turnover of international firms of 2.2 percent. Given that the average turnover of domestic firms in these regressions is 0.9 , this means that an 11 percent increase in this variable leads to a 6.1 percent increase in the domestic turnover of international firms, where the average domestic turnover of international firms is about 0.55. After controlling for the internationalization dummy and average turnover, however, the other variables add little explanatory power. The only exceptions are the size of the stock market (market capitalization/GDP) and to a lower extent the Edison and Warnock (2003) liberalization measure. ${ }^{11,12}$

\subsubsection{Migration: Private Placements and Level I ADRs}

As a robustness check, we examine firms that internationalize in a manner that does not provide a mechanism for their shares to be easily traded on an international public exchange. Thus, if migration is driving the earlier results in Table I, we should not observe a negative coefficient on the internationalization dummy when examining this sub-sample of firms, for which migration is less likely. More specifically, we examine firms that internationalize (i) through private placements in international markets or (ii) by cross-listing on the U.S. over-the-counter (OTC) market through Level I ADR programs. Level I ADRs are quoted on the Pink Sheets Electronic Quotation Service

\footnotetext{
${ }^{11}$ To estimate whether the variables of interest explain the high R-squares reported in the table, we ran the regressions using only country and year dummies plus assets and compared this R-square with those of the regressions in the table. In essence, we compute the partial R-square of the variables on which we are focusing the analysis. This provides a very conservative estimate because it overestimates the explanatory power of the country and year dummies. Specifically, none of the relation between domestic trading of international firms and the components of the variables of interest that are associated with the dummy variables and assets is assigned to the variables of interest. We find that the Internationalization Dummy and the average turnover of domestic firms account for about 15 percent of the regression Rsquare. Running the regressions only with the variables of interest yields an R-square of 0.38 .

${ }^{12} \mathrm{We}$ also examined the degree to which the association between the domestic turnover of each international firm and the average turnover of domestic firms arises from time-series or cross-sectional relations. We computed the within and between R-squares, where the within R-square is the R-square of a regression in deviations from the mean and the between R-square is the R-square of a cross-sectional regression using the sample averages of the variables. We estimated each of these regressions excluding and including the average turnover of domestic firms, always including the other variables in the regression. The results indicate that the average turnover of domestic firms explains more than 10 percent of the total within-country variation in the data and about 35 percent of the total between-country variation. Thus, the association between the domestic turnover of each international firm and the average turnover of domestic firms arises from both time-series and cross-sectional variation in the data.
} 
and/or the OTC Bulletin Board for use by a network of security dealers that make markets in the particular securities. This arrangement is much more cumbersome and costly than trading on a major public exchange. Similarly, while private placements under rule 144A in the U.S. are traded on the electronic PORTAL system among qualified institutions, internationalization in this manner does not provide a vehicle for firms to have their shares as widely and inexpensively traded as in a major public stock market. For comparison purposes, therefore, we examine this subset of firms for which migration will tend to be more difficult than for those that internationalize through cross-listing or issuing depositary receipts in a public exchange. As above, in defining the date of internationalization, we use the firm's first internationalization activity. In terms of estimation, we use the same specification and econometric techniques as in Equation (1).

As shown in Table II, internationalization that does not provide a vehicle for trading shares abroad on organized exchanges is not associated with a reduction in the turnover of the firm's shares in the local market. That is, the internationalization dummy does not enter negatively. Rather, we find that raising capital through private placements abroad or cross-listing on the U.S. OTC market through Level I ADRs tends to boost the trading of the firm's shares in the domestic market. This positive effect is significant at the five percent level in regressions 1-5 and at the ten percent level when using clustering at the firm level. This positive relation could represent a signaling effect, as investors in emerging markets increase their trading of firms that access capital in major financial centers. Although we do not identify the reasons underlying the positive relation between internationalization and domestic turnover for these firms, this result highlights our early findings on migration. When firms from emerging markets internationalize in a way that allows their shares to be traded abroad, they tend to experience a drop in trading activity in their own markets. 
The Table II regressions suggest that the migration results are not driven by reverse causality, whereby firms internationalize to flee from deteriorating domestic markets. As already noted, we control for domestic market conditions. Moreover, the Table II regressions show that firms that internationalize without providing a mechanism to have their shares traded in public markets abroad experience an increase, not a decrease, in domestic trading activity, which runs counter to the fleeing argument. Furthermore, Claessens et al. (2005) show that firms from countries with good economic and institutional fundamentals are more likely to access and trade in international capital markets, which also runs counter to the view that firms from countries with poor local environments are the one that internationalize. Thus, these robustness tests and related findings provide further support to the migration channel.

\subsubsection{Migration: Additional Evidence and Comments}

We provide additional evidence on the size of the migration effect and on the total trading activity of firms that internationalize by examining a subset of firms with detailed trading data in both domestic and international markets. Specifically, for firms that internationalize by issuing Level II and III American Depositary Receipts, we have data on the trading of their shares in both their local market and in New York. For these firms, we assess the degree to which trading actually shifts abroad after internationalization and what happens to the total trading of a firm's shares. We use the same basic specification provided in Equation (1), except that the dependent variable in Table III is total turnover of international firm $\mathrm{j}$ from country $\mathrm{c}$ in year $\mathrm{t}\left(T T_{j, c, t}^{I}\right)$, defined as the sum of its value traded domestically and abroad divided by its market capitalization, and the dependent variable in Table IV is the fraction of total turnover of international firm $\mathrm{j}$ from country $\mathrm{c}$ in year $\mathrm{t}$ that takes place in New York $\left(S T_{j, c, t}^{I}=\frac{T_{j, c, t}^{I}}{T T_{j, c, t}^{I}}\right)$. 
Tables III and IV show that (i) the total turnover of a firm soars after it internationalizes and (ii) the proportion of total trading that occurs in the local market plummets. ${ }^{13}$ Specifically, the coefficients in Table III show that the total turnover of international firms increases by around 38 percent following internationalization. ${ }^{14}$ Recall from Table I that the domestic turnover of international firms tends to fall after internationalization. Indeed, the estimated coefficients on the internationalization dummy in Table IV indicate that one plus the proportion of domestic trading of an international firm falls by about 21 percent following internationalization. Since this ratio equals two before internationalization (by definition), these estimates imply that the percentage of domestic trading of international firms falls to about 58 percent after a firm issues a Level II or III ADR.

The shift of trading to international market endures. That is, in our sample of emerging market firms there is no significant flow-back effect. In particular, we estimated the regressions from Table IV using a series of dummy variables that trace out annual patterns following internationalization. We found that the share of trading in international markets does not decrease over time.

These findings are consistent with migration. After controlling for many factors, we find that firms that internationalize by allowing their shares to be traded in major financial centers tend to experience a drop in the domestic market trading activity of their shares and a rise in total trading activity, as trading migrates abroad. Also consistent with migration, firms that internationalize without establishing a vehicle to have their shares traded internationally in major public exchanges do not experience a drop in their domestic market trading.

\footnotetext{
${ }^{13}$ Eun and Sabherwal (2003) find that the higher the fraction of trading occurring in international financial centers, the higher is the contribution of these international markets to price discovery.

${ }^{14}$ Following the same method as above for illustrating the economic magnitudes of these estimated relations, the estimated coefficient indicates that one plus the total turnover ratio of firm $\mathrm{j}$ from country $\mathrm{c}$ in year $\mathrm{t}$ rises by about 18 percent following internationalization. This increase is large given that the average value of the total turnover of international firms included in these regressions is about 0.89 , which means that for the average firm, total turnover rises by 38 percent after it internationalizes.
} 
In these analyses, we focused on trading activity, not liquidity, for two reasons. First, we want to assess a possible two-step mechanism linking internationalization with the liquidity of domestic firms. The first step involves migration: Does a firm's domestic trading activity shift out of the domestic market and into international financial centers after it internationalizes? Consequently, we examine trading, not liquidity. Second, it is conceptually difficult to measure the liquidity of a stock that is traded in more than one market. The majority of the trading could occur in New York, for example, where the price is established. In this case, there might be no link between trading and prices in the local market. Therefore, it would be inappropriate to conclude that the local market is more or less liquid based on price-impact liquidity measures. We now turn to a different issue: the relation between migration and the liquidity of domestic firms. Does the domestic trading of firms that have internationalized influence the liquidity of domestic firms as suggested by the migrationspillover view? Is there a connection between internationalization and domestic market liquidity beyond the migration-spillover effect? In particular, is the location of trading activity of international firms associated with the liquidity of domestic firms?

\subsection{SPILLOVERS AND THE INTERNATIONAL MARKET}

This section evaluates whether the aggregate trading of international firms in the domestic market and the share of trading activity taking place abroad affect the trading activity and liquidity of individual domestic firms. To conduct this test, we begin by examining whether the trading activity of a domestic equity varies with the aggregate domestic trading activity of international firms. Then, we use two specific measures of liquidity to assess whether the liquidity of a domestic equity varies with the aggregate domestic trading activity of international firms. Finding that trading activity and liquidity of individual domestic firms are positively associated with the aggregate trading activity of international firms in the local market after controlling for firm, country, and time-specific factors 
would constitute evidence of spillovers. We also analyze whether the share of a country's total trading taking place abroad affects the turnover and liquidity of individual domestic firms. Finding a negative relation between the share of trading occurring in international markets and the liquidity of domestic equities, would show that internationalization has a negative impact on domestic markets beyond the migration-spillover channel.

\subsubsection{Spillovers and the International Market: Trading Activity}

In Table $\mathrm{V}$, we assess whether the turnover ratio of domestic firm $\mathrm{j}$ from country $\mathrm{c}$ in year $\mathrm{t}$ $\left(T_{j, c, t}^{D}\right)$ is related to the average domestic turnover of public international firms from country c in year $\mathrm{t}\left(T_{c, t}^{I}\right)$. In testing for spillovers, we only examine the domestic trading activity of international firms that are traded in public markets abroad, as the evidence presented above shows that the domestic turnover of these firms tends to fall following internationalization. Thus, $T_{c, t}^{I}$ does not include the domestic trading activity of firms that internationalized through private placements or through the OTC market. ${ }^{15}$ The following specification is estimated:

$$
T_{j, c, t}^{D}=\phi \times A_{j, c, t}+\beta \times T_{c, t}^{I}+\gamma \times S T_{c, t}^{I}+\theta \times C_{c, t}+\delta_{1} \times n_{c}+\delta_{2} \times \tau_{t}+\varepsilon_{j, c, t} .
$$

As in the migration regressions, we estimate Newey-West standard errors, which are robust to heteroskedasticity and autocorrelation within firms, and also report firm-level clustered standard errors. We include country and year dummy variables as well. Furthermore, we incorporate the same time-varying firm and country characteristics discussed and defined in the subsection on migration. By conditioning on these variables, the goal is to identify the independent relation between the trading of international firms in the local market and the trading activity (and later liquidity) of individual domestic firms.

\footnotetext{
15 The results hold when using the domestic turnover of all international firms. This supports the basic principle of
} spillovers: The aggregate activity of a market influences the liquidity of individual shares. 
The results are consistent with large spillovers. The coefficient on $T_{c, t}^{I}$ enters positively and significantly at the one percent level in all of the specifications in Table V. The spillover effects are economically relevant. The size of the coefficient in regression 5 of Table V implies that the average domestic firm will experience a five percent reduction in its turnover when the average domestic turnover of international firms falls by 12 percent. ${ }^{16}$ Thus, the estimated coefficients suggest an economically large relation between the trading of an individual domestic firm and the aggregate trading of international firms on the local market.

We find these spillover effects when controlling for many country and firms characteristics. In particular, after conditioning on country and year dummy variables, the size of the domestic firm, the level of economic development, the size of the local stock market, and indicators of stock market liberalization, we find evidence consistent with spillovers. Furthermore, the estimated size of the spillover effect does not vary much when using various combinations of these control variables.

The fraction of trading that occurs in international financial centers enters negatively and significantly. Even when controlling for many country traits and while controlling for the domestic trading of international firms, we find that the fraction of trading activity that occurs abroad is negatively associated with the domestic trading activity of domestic firms. While it is impossible to pin one interpretation to the coefficient on this variable, the results suggest that something beyond the migration and spillover channel links internationalization and domestic markets. For example, the results indicate that as New York becomes a more important trading place for Mexican stocks (relative to the total trading of Mexican stocks), the turnover of domestic Mexican stocks declines.

\footnotetext{
${ }^{16}$ The coefficient shows that a five percent increase in one plus the average domestic turnover of international firms leads to an increase of three percent in one plus the turnover of domestic firms. Given that the average domestic turnover of international firms (in this regression) is 0.68 and the average turnover of domestic firms is 1.35 , these implies that that the average domestic firm's stock will experience a five percent reduction in its turnover when the average domestic turnover of international firms falls by 12 percent.
} 
Thus, according to this measure, internationalization is associated with a drop in the trading of domestic firms, even after controlling for local market conditions.

Finally, note that the logarithm of total assets enters negatively in these regressions. This is because assets are very highly correlated with market capitalization, and the dependent variable (turnover) has market capitalization in its denominator. In the tables below where we examine specific measures of illiquidity, we find a negative relation between firm size and illiquidity.

\subsubsection{Spillovers and the International Market: Amihud Illiquidity Index}

Next, we examine the impact of internationalization on the liquidity of domestic equities, using daily data to compute Amihud's (2002) illiquidity index. Liquidity is a complex concept that is not observed directly. While many authors use turnover as a proxy for liquidity, turnover does not directly measure trading costs or the price impact of transactions. Bid-ask spread measures of trading costs do not exist for the bulk of our sample, so we compute a price-impact measure. Since Hasbrouck (2005) finds that, within the class of price-impact liquidity estimates, Amihud's (2002) illiquidity index is the most reliable proxy of trading costs, we start with this measure.

Amihud's (2002) illiquidity index is defined as the average ratio of absolute return to trading value. Based on daily data, the illiquidity ratio is defined as follows

$$
I_{j, c, t}=\frac{1}{D_{j, c, t}} \sum_{d=1}^{D_{j, c, t}} \frac{\left|\Delta P_{j, c, d, t}\right|}{V_{j, c, d, t}} .
$$

Where $I_{j, c, t}$ is the illiquidity ratio of firm $\mathrm{j}$ from country $\mathrm{c}$ in year $\mathrm{t}, \Delta P_{j, c, d, t}$ is the percent change in the stock price of firm $\mathrm{j}$ from country $\mathrm{c}$ on day $\mathrm{d}$ of year $\mathrm{t}, V_{j, c, d, t}$ is the value traded of firms' $\mathrm{j}$ stock from country c on day d of year $\mathrm{t}$, and $D_{j, c, t}$ is the number of days for which the ratio can be calculated for firm $\mathrm{j}$ from country $\mathrm{c}$ in year $\mathrm{t}$. The index is multiplied by $10^{6}$ so the results are easier 
to read. This index relates the absolute value of price movement to the value of equity transactions. This measure follows Kyle's (1985) concept of liquidity, the response of price to order flow.

We compute this illiquidity index using daily data on share prices in dollars, so that it can be interpreted as the percent price response to one dollar worth of trading, allowing for comparison across countries. As an alternative, we also followed the methodology used by Lesmond (2005), estimating the illiquidity index using daily prices in local currency and then converting the annual index into dollars using the average exchange rate over the year to allow for a comparison across countries. We obtained very similar results to those reported below. We use the same specification as in Equation (2), except now the dependent variable is Amihud's illiquidity index $\left(I_{j, c, t}^{D}\right)$. In our sample, this illiquidity measure is correlated with turnover. For domestic firms, the simple correlation coefficient is -0.33 (significant at the one percent level), that is, as turnover increases illiquidity decreases.

The results presented in Table VI provide additional evidence for liquidity spillovers. Average turnover of public international firms in the domestic market (measured in logarithms) enters negatively and significantly at the one percent level in all of the illiquidity regressions. This suggests that less domestic trading of international firms is associated with a drop in the liquidity (higher Amihud illiquidity index) of domestic firm shares. Again, these results hold when conditioning on a wide assortment of information. Furthermore, the spillover effects from the domestic trading of international firms to the liquidity of domestic stocks are relevant, though not enormous. The size of the coefficient in regression 5 of Table VI suggests that the illiquidity index of the typically domestic firm will jump by about two percent when the domestic turnover of international firms falls by 10 
percent. ${ }^{17}$ Since internationalization is associated with a drop in the domestic turnover of the average internationalizing firm of about 17 percent (Table I), these estimates suggest a non-negligible link between internationalization and the liquidity of domestic firms.

We also find that the illiquidity of a domestic stock is positively associated with the share of trading occurring in international markets. This holds even when controlling for local market conditions, including the domestic trading of international firms. Thus, while the results in Table VI support the hypothesis of spillovers, the results also indicate that as trading abroad increases in relative terms, the liquidity of domestic firms falls. This effect is independent of spillover effects.

\subsubsection{Spillovers and the International Market: Zero Return Illiquidity Measures}

We finally consider an additional measure of the illiquidity of domestic stocks. $Z R_{j, c, t}^{D}$ equals the fraction of trading days in a year $t$ when a firm's stock (firm $\mathrm{j}$ from country $\mathrm{c}$ ) experienced zero returns. As mentioned in the Introduction, the literature has recently used illiquidity measures based on the proportion of zero-return days. Lesmond et al. (1999) argue that if the value of information is insufficient to outweigh the costs associated with transacting, then market participants will choose not to trade, resulting in an observed zero return. Therefore, the proportion of zero returns is associated with transaction costs. In our data, the proportion of zero-return days is positively correlated with the Amihud measure and negatively correlated with turnover, with the correlations being 0.42 and -0.33 , respectively, and in both cases significant at the one percent level. Although there is greater theoretical appeal to using price-impact liquidity measures, such as the Amihud ratio employed above, we use this additional measure of liquidity as a robustness check. We also created an additional indicator of liquidity, equal to the fraction of trading days in year $\mathrm{t}$ when a firm's stock

\footnotetext{
${ }^{17}$ Following the illustrative examples above, the regression estimates suggest that a five percent decrease in one plus the average domestic turnover of international firms is associated with an increase of one percent in one plus the Amihud illiquidity ratio of domestic firms. Given that the average domestic turnover of international firms for the sample included in this specification is 0.71 and the average illiquidity index for domestic firms is 0.81 , this means that the illiquidity of domestic firms tends to rise by two percent when there is a 12 percent decrease in domestic trading of international firms.
} 
(firm $\mathrm{j}$ from country c) experienced zero trading, that is zero returns and no trading activity. Holding other things constant, more days with no trading suggests less liquidity. When we use this as the dependent variable, we find very similar results. We compute this measure using daily price data in domestic currency, as returns calculated using data in foreign currency may be affected by exchange rate volatility.

The results in Table VII are consistent with spillovers. The domestic trading of international firms is negatively associated with illiquidity. In particular, there is a negative and significant (at the one percent level) relation between the proportion of days with zero returns and the logarithm of one plus the average turnover of public international firms in the domestic market. Thus, a reduction in the domestic trading of international firms is associated with an increase in the number days that domestic firms experience zero returns. Moreover, confirming previous results, when trading abroad as a share of total trading increases, the proportion of zero return days by domestic firms increases, i.e. domestic firms become more illiquid.

\section{Conclusion}

In this paper, we find evidence that supports the view that internationalization has a negative impact on domestic stock market liquidity. First, the evidence is broadly consistent with the two-part migration-spillover view of internationalization. When a firm cross-lists or issues depositary receipts in an international public exchange (e.g., the NYSE), we find that the trading of the firm's shares tends to migrate out of the domestic market and into the international market. Furthermore, there is strong evidence of spillovers in stock markets. The liquidity of individual domestic firms is positively associated with the aggregate domestic trading activity of international firms even when controlling for domestic market conditions, country characteristics, and firm traits. Thus, there is some evidence 
for policymakers concerns that firms that cross-list or issue depositary receipts in major public exchanges facilitate the migration of trading out of the domestic market, which hurts the liquidity of domestic firms.

Second, we find that migration and spillovers are not the only links between internationalization and the liquidity of domestic firms. In particular, the aggregate share of trading abroad is negatively associated with the liquidity of domestic firms. Thus, even when controlling for the migration-spillover channel and domestic market conditions, a domestic firm's liquidity is negatively linked with the proportion of trading from the same country that takes place aboard. The findings are consistent with arguments that investors seeking to hold country-specific risk shift their trading of a country's stocks to lower cost, lower risk international markets when firms from that country internationalize. This reduces their trading of domestic firms in the local market, with negative repercussions on the liquidity of these firms. The findings are also consistent with arguments that internationalization signals that a firm is of comparatively high quality, which might then have adverse implications on the liquidity of domestic firms. Thus, substantially more research is needed into decomposing the relation between internationalization and the drop in domestic firm liquidity.

The estimated effects suggest that internationalization is associated with important distributional effects. Firms that internationalize experience a substantial increase in the total (domestic plus international) trading of their shares. However, the migration of their trading out of the domestic market and into international markets is tied to a substantive drop in the liquidity of domestic firms. Thus, internationalization is associated with large distributional changes to liquidity across firms. These effects are relevant because, as shown by Amihud and Mendelson (1986), firm liquidity influences the cost of capital. It would be valuable for future research to explore more fully the country, industry, and firm characteristics that drive corporate internationalization decisions and 
to investigate whether domestic firms receive countervailing benefits from the internationalization process.

The liquidity spillovers in markets around the world documented in this paper are important by themselves, even beyond the migration of trading out of local markets. These spillover effects suggest that there is a powerful force for the consolidation of trading within a few markets. This consolidation may occur both within a country and across international markets. This paper has shown that for international firms from emerging economies the relevant market might exist outside the borders of their home markets. On the other hand, Halling et al. (2005) find that for European cross-listed firms the relevant market is within their home country. These differences suggest that markets of different sizes and quality may have different "gravitational pulls" on the trading activity of cross-listed firms. More research is needed to understand the determinants and implications of these different equilibria. 


\section{References}

Aggarwal, R., Klapper, L., and Wysocki, P. (2005) Portfolio preferences of foreign institutional investors, Journal of Banking and Finance 29, 2919-2946.

Alexander, G., Eun, C., and Janakiramanan, S. (1988) International listings and stock returns: Some empirical evidence, Journal of Financial and Quantitative Analysis 23, 135-151.

Alexander, G., Eun, C., and Janakiramanan, S. (1987) Asset pricing and dual listing on foreign capital markets: A note, Journal of Finance 42, 151-158.

Amihud, Y. (2002) Illiquidity and stock returns: Cross-section and time-series effects, Journal of Financial Markets 5, 31-56.

Amihud, Y. and Mendelson, H. (1986) Asset pricing and the bid-ask spread, Journal of Financial Economics 17, 223-249.

Atkins, A. B. and Dyl, E. A. (1997) Transactions costs and holding periods for common stocks, Journal of Finance 52, 309-325.

Beck, T. and Levine, R. (2004) Stock Markets, banks, and economic growth: Panel evidence, Journal of Banking and Finance 28, 423-442.

Beck, T. and Levine, R. (2002) Industry growth and capital allocation: Does having a market- or bank-based system matter?, Journal of Financial Economics 64, 147-180.

Bekaert, G., Harvey, C. R., and Lundblad, C. (2005) Does financial liberalization spur growth?, Journal of Financial Economics 77, 3-55

Bovespa (1996) Nova York ataca e os mercados reagem, Revista Bovespa, May.

Bradshaw, M. T., Bushee, B. J., and Miller, G. S. (2004) Accounting choice, home bias, and U.S. investment in non-U.S. firms, Journal of Accounting Research 42, 795-841. 
Brennan, M. J., Chordia, T., and Subrahmanyam, A. (1998) Alternative factor specifications, security characteristics and the cross-section of expected stock returns, Journal of Financial Economics 49, 345-373.

Cantale, S. (1996), The choice of a foreign market as a signal, unpublished working paper, Tulane University.

Chordia, T., Roll, R., and Subrahmanyam, A. (2000) Commonality in liquidity, Journal of Financial Economics 56, 3-28.

Chowdhry, B. and Nanda, V. (1991) Multimarket trading and market liquidity, Review of Financial Studies 4, 483-511.

Claessens, S., Klingebiel, D., and Schmukler, S. (2005) Stock market development and internationalization: Do economic fundamentals spur both similarly?, Journal of Empirical Finance, forthcoming..

Coughenour, J. F. and Saad, M. M. (2004) Common market makers and commonality in liquidity, Journal of Financial Economics 73, 37-69.

Datar, V. T., Naik, N. Y., and Radcliffe, R. (1998) Liquidity and stock returns: An alternative test, Journal of Financial Markets 1, 205-219.

Demirguc-Kunt, A. and Maksimovic, V. (1998) Law, finance, and firm growth, Journal of Finance 53, 2107-2137.

Doidge, C. A., Karolyi, A., and Stulz, R. M. (2004) Why are firms that list in the U.S. worth more?, Journal of Financial Economics 71, 205-238.

Domowitz, I., Glen, J., and Madhavan, A. (1998) International cross-listing and order flow migration: Evidence from an emerging market, Journal of Finance 53, 2001-2027. 
Edison, H. and Warnock, F., (2004) U.S. investors' emerging market equity portfolios: A securitylevel analysis, Review of Economics and Statistics 86, 691-704.

Edison, H. and Warnock, F. (2003) A Simple measure of the intensity of capital controls, Journal of Empirical Finance 10, 81-103.

Eun, C. and Sabherwal, S. (2003) Cross-border listings and price discovery: Evidence from US-listed Canadian stocks, Journal of Finance 58, 549-574.

Federation des Bourses de Valeurs (2000) Price discovery and the competitiveness of trading systems.

Financial Times (1998) ADRs prove a double-edged sword, April 6.

Foerster, S. and Karolyi, A. (1999) The effects of market segmentation and investor recognition on asset prices: Evidence from foreign stocks listing in the United States, Journal of Finance 54, 981-1013.

Fuerst, O. (1998), A theoretical analysis of the investor protection regulations argument for global listing of stocks, unpublished working paper, Yale University.

Gozzi, J. C., Levine, R., and Schmukler, S. (2005), Internationalization and the evolution of corporate valuation, unpublished working paper, Brown University, previously released as NBER Working Paper No. 11023.

Halling, M., Pagano, M., Randl, O., and Zechner, J. (2005) Where is the market? Evidence from cross-listings, CEPR Discussion Paper No. 4987.

Hargis, K. (2000) International cross-listing and stock market development in emerging economies, International Review of Economics and Finance 9, 101-122. 
Hargis, K. (1998), When does multimarket trading improve the quality of the primary market? Evidence from international cross-listings, unpublished working paper, Goldman, Sachs and Co.

Hargis, K. and Ramanlal, P. (1998) When does internationalization enhance the development of domestic stock markets?, Journal of Financial Intermediation 7, 263-292.

Hasbrouck, J. (2005), Trading costs and returns for U.S. equities: The evidence from daily data, unpublished working paper, New York University Stern School of Business Department of Finance.

Hasbrouck, J. and Seppi, D. J. (2004) Common factors in prices, order flows, and liquidity, Journal of Financial Economics 59, 383-411.

Haugen, R. A. and Baker, N. L. (1996) Commonality in the determinants of expected stock returns, Journal of Financial Economics 41, 401-439.

Henry, P. (2000) Stock market liberalization, economic reform, and emerging market equity prices, Journal of Finance 55, 529-564.

Karolyi, A. (2006) The world of cross-listings and cross-listings of the world: Challenging conventional wisdom, Review of Finance, this volume.

Karolyi, A. (2004) The role of ADRs in the development and integration of emerging equity markets, Review of Economics and Statistics 86, 670 - 690.

Kyle, A. S. (1985) Continuous auctions and insider trading, Econometrica 53, 1315-1335.

Lang, M., Lins, V., and Miller, D. (2003) ADRs, analysts, and accuracy. Does cross listing in the United States improve a firm's information environment and increase market value?, Journal of Accounting Research 41, 317-345.

Latin Finance (1999) The incredible shrinking markets, September. 
Latin Finance (2004) Beware of the bull, December.

Lesmond, D. A. (2005) Liquidity of emerging markets, Journal of Financial Economics 77, 411-452.

Lesmond, D. A., Ogden, J. P., and Trzcinka, C. A. (1999) A new estimate of transaction costs, Review of Financial Studies 12, 1113-1141.

Levine, R. (1991) Stock markets, growth, and tax policy, Journal of Finance 46, 1445-1465.

Levine, R. and Schmukler, S. (2003) Migration, spillover, and trade diversion: The impact of internationalization on domestic stock market activity, NBER Working Paper No. 9614.

Levine, R. and Zervos, S. (1998a) Stock markets, banks, and economic growth, American Economic Review 88, 537-558.

Levine, R. and Zervos, S. (1998b) Capital control liberalization and stock market development, World Development 26, 1169-1184.

Miller, D. (1999) The market reaction to international cross-listings: Evidence from depositary receipts, Journal of Financial Economics 51, 103-123.

Moel, A. (2001) The role of American Depositary Receipts in the development of emerging markets, Economia 2, 209-273.

Noronha, G., Sarin, A., and Saudagaran, S. (1996) Testing for microstructure effects of international dual listings using intraday data, Journal of Banking and Finance 20, 965-983.

Pagano, M., Roell, A., and Zechner, J. (2002) The geography of equity listing: Why do European companies list abroad?, Journal of Finance 57, 2651-2694.

Patro, D. (2000) Return behavior and pricing of American Depositary Receipts, Journal of International Financial Markets, Institutions and Money 10, 43-67.

Petersen, M. and Fialkowski, D. (1994) Posted versus effective spreads: Good prices or bad quotes, Journal of Financial Economics 35, 269-292. 
Pulatkonak, M. and Sofianos, G. (1999) The distribution of global trading in NYSE-listed non-U.S. stocks, NYSE Working Paper 99-03.

Reese, W. A. and Weisbach, M. S. (2002) Protection of minority shareholder interest, cross-listings in the United States, and subsequent equity offerings, Journal of Financial Economics 66, 65104.

Rouwenhorst, K.G. (1999) Local return factors and turnover in emerging stock markets, Journal of Finance 54, 1439-1463.

Schmukler, S. and Vesperoni, E. (2006) Financial globalization and debt maturity in emerging economies, Journal of Development Economics 79, 183-207.

Siegel. J. (2005) Can foreign firms bond themselves effectively by submitting to U.S. law?, Journal of Financial Economics 75, 319-360.

Stoll, H. R. (1978a) The supply of dealer services in securities markets, Journal of Finance 33, 11331151.

Stoll, H. R. (1978b) The pricing of security dealers services: An empirical study of NASDAQ Stocks, Journal of Finance 33, 1153-1172.

Stulz, R. M. (1999) Globalization, corporate finance, and the cost of capital, Journal of Applied Corporate Finance 12, 8-25.

The Economist (2000) Latin America's stock markets: High and dry, February 19.

Velli, J. (1994) American Depositary Receipts: An overview, Fordham International Law Journal 17, 38-57.

Vinhas de Souza, L. (2005). Financial liberalization and business cycles: The experience of the new EU member states, in: J. Batten and C. Kearney (eds.) Emerging European Financial Markets: Independence and Integration Post-enlargement, Elsevier, Netherlands. 
World Bank (2004) Whither Latin American capital markets?, www.worldbank.org/laccapitalmarkets. 


\section{Table I}

\section{Domestic Trading Activity of International Firms: Publicly Listed Firms}

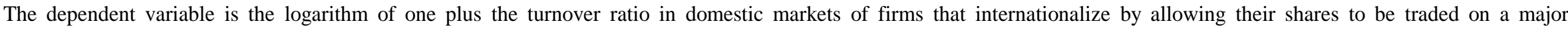

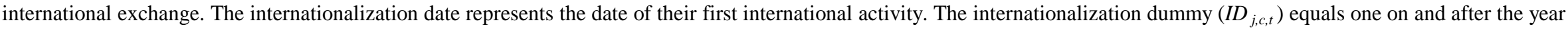

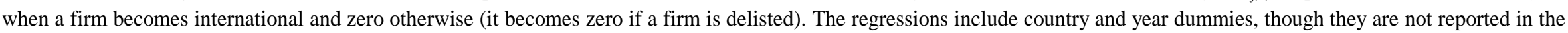

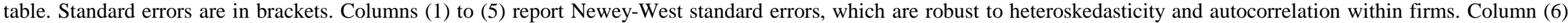
reports standard errors adjusted for clustering at the firm-level. *,**,*** mean significance at ten, five, and one percent, respectively. The estimated equation is the following:

$$
T_{j, c, t}^{I}=\phi \times A_{j, c, t}+\alpha \times I D_{j, c, t}+\beta \times T_{c, t}^{D}+\gamma \times S T_{c, t}^{I}+\theta \times C_{c, t}+\delta_{1} \times n_{c}+\delta_{2} \times \tau_{t}+\varepsilon_{j, c, t}
$$

\section{Dependent Variable: \\ Log (1+Domestic Turnover)}

Log of Total Assets $\mathrm{j}_{\mathrm{j}, \mathrm{t}}$

Internationalization Dummy $\mathrm{j}_{\mathrm{j}, \mathrm{c}, \mathrm{t}}$

Log (1+ Average Turnover of Domestic Firms) $)_{c, t}$

Stock Market Liberalization Dummy ${ }_{\mathrm{c}, \mathrm{t}}$

Log of $(1+\text { Value Traded Abroad/Total Value Traded })_{c, t}$

Stock Market Liberalization

Edison and Warnock (2003) Measure $_{c, t}$

Log of GDP per capita ${ }_{c, t}$

Market Capitalization / GDP ${ }_{\mathrm{c}, \mathrm{t}}$

Country Dummies

Year Dummies

Number of Observations

Number of Firms

Number of Countries

R-squared

\begin{tabular}{|c|c|c|c|c|c|}
\hline (1) & (2) & (3) & (4) & (5) & (6) \\
\hline-0.012 & -0.008 & -0.004 & -0.007 & -0.004 & -0.004 \\
\hline [0.008] & [0.008] & [0.007] & [0.008] & [0.007] & [0.010] \\
\hline$-0.053 * *$ & $-0.051 * *$ & $-0.056 * *$ & $-0.056 * *$ & $-0.061 * *$ & $-0.061 *$ \\
\hline$[0.025]$ & [0.025] & {$[0.025]$} & [0.026] & {$[0.025]$} & [0.033] \\
\hline $0.423 * * *$ & $0.440 * * *$ & $0.432 * * *$ & $0.388 * * *$ & $0.434 * * *$ & $0.434 * * *$ \\
\hline \multirow[t]{10}{*}{ [0.050] } & {$[0.051]$} & [0.056] & [0.053] & {$[0.054]$} & {$[0.055]$} \\
\hline & 0.006 & 0.005 & & -0.006 & -0.006 \\
\hline & [0.035] & {$[0.036]$} & & [0.037] & [0.034] \\
\hline & & 0.026 & -0.058 & 0.011 & 0.011 \\
\hline & & [0.097] & [0.108] & [0.098] & [0.097] \\
\hline & & & $\begin{array}{c}0.113 * \\
{[0.065]}\end{array}$ & & \\
\hline & & & & 0.008 & 0.008 \\
\hline & & & & [0.054] & [0.062] \\
\hline & & & & $0.125 * * *$ & $0.125 * * *$ \\
\hline & & & & [0.040] & [0.037] \\
\hline
\end{tabular}

\begin{tabular}{rrrrrr} 
Yes & Yes & Yes & Yes & Yes & Yes \\
Yes & Yes & Yes & Yes & Yes & Yes \\
\hline 1,516 & 1,419 & 1,390 & 1,385 & 1,390 & 1,390 \\
264 & 236 & 235 & 231 & 235 & 235 \\
36 & 32 & 32 & 25 & 32 & 32 \\
0.51 & 0.51 & 0.48 & 0.50 & 0.48 & 0.48 \\
\hline
\end{tabular}




\section{Table II}

\section{Domestic Trading Activity of International Firms: Private Placements and Level I ADRs}

The dependent variable is the logarithm of one plus the turnover ratio in domestic markets of firms that internationalize through private placements in international financial centers or by cross-listing on the U.S. over-the-counter (OTC) market through Level I ADR programs. The internationalization date represents the date of their first international activity. The internationalization dummy $\left(I D_{j, c, t}\right)$ equals one on and after the year when a firm becomes international and zero otherwise (it becomes zero if a firm is delisted). Firms are excluded from the regressions if and when they become publicly traded in international equity markets. The regressions include country and year dummies, though they are not reported in the table. Standard errors are in brackets. Columns (1) to (5) report Newey-West standard errors, which are robust to heteroskedasticity and autocorrelation within firms. Column (6) reports standard errors adjusted for clustering at the firm-level. *,**,*** mean significance at ten, five, and one percent, respectively. The estimated equation is the following:

$$
T_{j, c, t}^{I}=\phi \times A_{j, c, t}+\alpha \times I D_{j, c, t}+\beta \times T_{c, t}^{D}+\gamma \times S T_{c, t}^{I}+\theta \times C_{c, t}+\delta_{1} \times n_{c}+\delta_{2} \times \tau_{t}+\varepsilon_{j, c, t}
$$

\begin{tabular}{|c|c|c|c|c|c|c|}
\hline \multicolumn{7}{|c|}{$\begin{array}{c}\text { Dependent Variable: } \\
\text { Log (1+Domestic Turnover) }\end{array}$} \\
\hline & $(1)$ & $(2)$ & $(3)$ & $(4)$ & $(5)$ & $(6)$ \\
\hline Log of Total Assets ${ }_{j, c, t}$ & $\begin{array}{c}-0.014 * \\
{[0.008]}\end{array}$ & $\begin{array}{l}-0.017 \text { ** } \\
{[0.008]}\end{array}$ & $\begin{array}{l}-0.018 * * \\
{[0.008]}\end{array}$ & $\begin{array}{l}-0.015 * * \\
{[0.008]}\end{array}$ & $\begin{array}{l}-0.020 * * \\
{[0.008]}\end{array}$ & $\begin{array}{r}-0.020 \\
{[0.013]}\end{array}$ \\
\hline Internationalization Dummy $\mathrm{j}_{\mathrm{j}, \mathrm{c}, \mathrm{t}}$ & $\begin{array}{l}0.077 * * * \\
{[0.023]}\end{array}$ & $\begin{array}{l}0.082 * * * \\
{[0.024]}\end{array}$ & $\begin{array}{l}0.067 * * * \\
{[0.023]}\end{array}$ & $\begin{array}{l}0.067 * * * \\
{[0.023]}\end{array}$ & $\begin{array}{l}0.062 * * * \\
{[0.023]}\end{array}$ & $\begin{array}{l}0.062 * \\
{[0.032]}\end{array}$ \\
\hline Log $(1+\text { Average Turnover of Domestic Firms })_{c, t}$ & $\begin{array}{l}0.543 * * * \\
{[0.049]}\end{array}$ & $\begin{array}{l}0.560 * * * \\
{[0.052]}\end{array}$ & $\begin{array}{l}0.508 * * * \\
{[0.050]}\end{array}$ & $\begin{array}{l}0.470 * * * \\
{[0.049]}\end{array}$ & $\begin{array}{l}0.529 * * * \\
{[0.048]}\end{array}$ & $\begin{array}{l}0.529 * * * \\
{[0.049]}\end{array}$ \\
\hline Stock Market Liberalization Dummy $y_{c, t}$ & & $\begin{array}{r}0.012 \\
{[0.027]}\end{array}$ & $\begin{array}{r}-0.005 \\
{[0.028]}\end{array}$ & & $\begin{array}{r}-0.007 \\
{[0.029]}\end{array}$ & $\begin{array}{r}-0.007 \\
{[0.036]}\end{array}$ \\
\hline Log of $(1+\text { Value Traded Abroad/Total Value Traded })_{c, t}$ & & & $\begin{array}{l}-0.219 * * \\
{[0.098]}\end{array}$ & $\begin{array}{l}-0.290 * * * \\
{[0.093]}\end{array}$ & $\begin{array}{l}-0.223 * * \\
{[0.099]}\end{array}$ & $\begin{array}{l}-0.223 * \\
{[0.113]}\end{array}$ \\
\hline $\begin{array}{l}\text { Stock Market Liberalization } \\
\text { Edison and Warnock (2003) Measure } \text { c,t }\end{array}$ & & & & $\begin{array}{l}0.189 * * * \\
{[0.057]}\end{array}$ & & \\
\hline Log of GDP per capita ${ }_{c, t}$ & & & & & $\begin{array}{r}0.058 \\
{[0.056]}\end{array}$ & $\begin{array}{r}0.058 \\
{[0.054]}\end{array}$ \\
\hline Market Capitalization / $\mathrm{GDP}_{\mathrm{c}, \mathrm{t}}$ & & & & & $\begin{array}{l}0.128 * * * \\
{[0.032]}\end{array}$ & $\begin{array}{l}0.128 * * * \\
{[0.026]}\end{array}$ \\
\hline Country Dummies & Yes & Yes & Yes & Yes & Yes & Yes \\
\hline Year Dummies & Yes & Yes & Yes & Yes & Yes & Yes \\
\hline Number of Observations & 1,720 & 1,554 & 1,525 & 1,622 & 1,525 & 1,525 \\
\hline Number of Firms & 293 & 248 & 247 & 274 & 247 & 247 \\
\hline Number of Countries & 37 & 32 & 32 & 28 & 32 & 32 \\
\hline R-squared & 0.54 & 0.56 & 0.54 & 0.51 & 0.54 & 0.54 \\
\hline
\end{tabular}




\section{Table III}

Total Trading Activity of International Firms: Firms with Level II and III ADRs

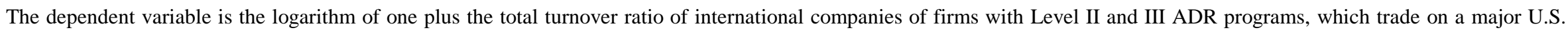

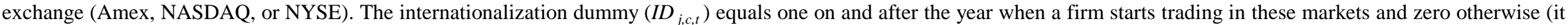

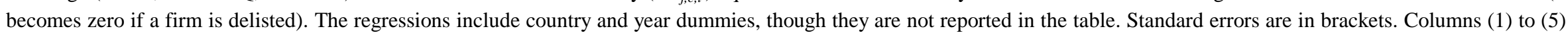

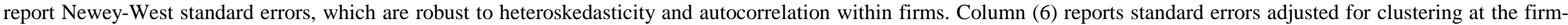
level. *,**,*** mean significance at ten, five, and one percent, respectively. The estimated equation is the following:

$$
T T_{j, c, t}^{I}=\phi \times A_{j, c, t}+\alpha \times I D_{j, c, t}+\beta \times T_{c, t}^{D}+\gamma \times S T_{c, t}^{I}+\theta \times C_{c, t}+\delta_{1} \times n_{c}+\delta_{2} \times \tau_{t}+\varepsilon_{j, c, t}
$$

\section{Dependent Variable: \\ Log (1+Total Turnover)}

Log of Total Assets $\mathrm{j}_{\mathrm{j}, \mathrm{t}, \mathrm{t}}$

Internationalization Dummy $\mathrm{j}_{\mathrm{j}, \mathrm{c}, \mathrm{t}}$

Log $(1+\text { Average Turnover of Domestic Firms })_{c, t}$

Stock Market Liberalization Dummy ${ }_{\mathrm{c}, \mathrm{t}}$

Log of $(1+\text { Value Traded Abroad/Total Value Traded })_{c, t}$

Stock Market Liberalization

Edison and Warnock (2003) Measure $_{\mathrm{c}, \mathrm{t}}$

Log of GDP per capita ${ }_{\mathrm{c}, \mathrm{t}}$

Market Capitalization / GDP ${ }_{c, t}$

Country Dummies

Year Dummies

Number of Observations

Number of Firms

Number of Countries

R-squared

\begin{tabular}{cc}
$(1)$ & $(2)$ \\
\hline$-0.046 * * *$ & $-0.039 * *$ \\
{$[0.015]$} & {$[0.016]$} \\
$0.196 * * *$ & $0.191 * * *$ \\
{$[0.038]$} & {$[0.038]$} \\
$0.395 * * *$ & $0.410 * * *$ \\
{$[0.084]$} & {$[0.088]$} \\
& -0.010 \\
& {$[0.047]$}
\end{tabular}

(3) (4)

(4)

$-0.030 * * \quad-0.039 * * *$

\begin{tabular}{ccc} 
& $(5)$ & $(6)$ \\
\hline$* * *$ & $-0.026 * *$ & -0.026 \\
$* * *$ & {$[0.013]$} & {$[0.016]$} \\
& $0.164 * * *$ & $0.164 * * *$ \\
$* * *$ & {$[0.040]$} & {$[0.044]$} \\
& $0.387 * * *$ & $0.387 * * *$ \\
& {$[0.084]$} & {$[0.058]$} \\
& -0.002 & -0.002 \\
& {$[0.048]$} & {$[0.046]$} \\
& $0.404 * * *$ & $0.404 * * *$ \\
& {$[0.132]$} & {$[0.136]$} \\
& & \\
& & \\
& $-0.220 * * *$ & $-0.220 * * *$ \\
& {$[0.081]$} & {$[0.069]$} \\
& -0.044 & -0.044 \\
& {$[0.076]$} & {$[0.077]$}
\end{tabular}

[0.014] [0.014]

$0.164 * * *$

$0.169 * * *$

[0.038]

$0.383 * * *$

[0.039]

[0.084]

$-0.017$

[0.049]

$0.361 *$

$0.361 * * *$

[0.084]

[0.129]

$* * *$

[0.142]

0.025

[0.101]

0.54

\begin{tabular}{rrr} 
Yes & Yes & Yes \\
Yes & Yes & Yes \\
\hline 696 & 655 & 64 \\
119 & 106 & 105 \\
20 & 18 & 18 \\
0.54 & 0.52 & 0.50 \\
\hline
\end{tabular}

\begin{tabular}{rr} 
Yes & Yes \\
Yes & Yes \\
\hline 645 & 658 \\
105 & 11 \\
18 & 18 \\
0.50 & 0.53
\end{tabular}

\begin{tabular}{rrr} 
Yes & Yes & Yes \\
Yes & Yes & Yes \\
\hline 658 & 645 & 645 \\
110 & 105 & 105 \\
18 & 18 & 18 \\
0.53 & 0.51 & 0.51 \\
\hline
\end{tabular}




\section{Table IV}

\section{Migration: Firms with Level II and III ADRs}

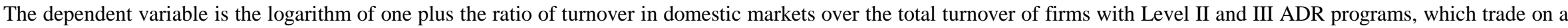

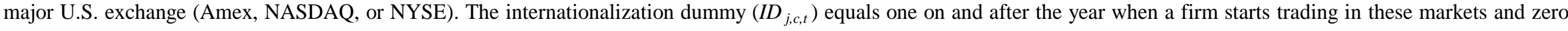

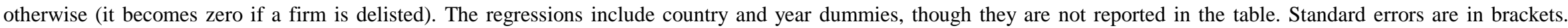

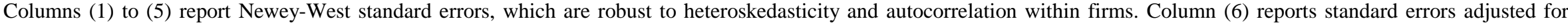
clustering at the firm-level. *,**,*** mean significance at ten, five, and one percent, respectively. The estimated equation is the following:

\begin{tabular}{|c|c|c|c|c|c|c|}
\hline \multicolumn{7}{|c|}{$\begin{array}{c}\text { Dependent Variable: } \\
\text { over in Domestic Market / Total Turnover) }\end{array}$} \\
\hline \multirow{3}{*}{ Log of Total Assets $\mathrm{j}_{\mathrm{j}, \mathrm{t}}$} & $(1)$ & (2) & (3) & (4) & $(5)$ & (6) \\
\hline & $0.013 * *$ & $0.016 * * *$ & $0.017 * * *$ & $0.013 * *$ & $0.014 * *$ & 0.014 \\
\hline & {$[0.006]$} & {$[0.006]$} & {$[0.006]$} & {$[0.006]$} & {$[0.006]$} & {$[0.011]$} \\
\hline \multirow[t]{2}{*}{ Internationalization Dummy $\mathrm{j}_{\mathrm{j}, \mathrm{c}, \mathrm{t}}$} & $-0.227 * * *$ & $-0.223 * * *$ & $-0.206 * * *$ & $-0.208 * * *$ & $-0.214 * * *$ & $-0.214 * * *$ \\
\hline & {$[0.017]$} & {$[0.017]$} & [0.019] & [0.019] & [0.019] & [0.029] \\
\hline \multirow{2}{*}{$\log (1+\text { Average Turnover of Domestic Firms })_{c, t}$} & $0.077 * * *$ & $0.088 * * *$ & $0.058 * *$ & 0.042 & $0.050 *$ & $0.050 *$ \\
\hline & {$[0.025]$} & {$[0.025]$} & {$[0.026]$} & {$[0.027]$} & {$[0.027]$} & {$[0.024]$} \\
\hline \multirow{2}{*}{ Stock Market Liberalization Dummy ${ }_{c, t}$} & & -0.043 & -0.037 & & $-0.050 * *$ & $-0.050 *$ \\
\hline & & {$[0.027]$} & {$[0.023]$} & & {$[0.024]$} & {$[0.028]$} \\
\hline \multirow{2}{*}{ Log of $(1+\text { Value Traded Abroad/Total Value Traded })_{c, t}$} & & & $-0.341 * * *$ & $-0.373 * * *$ & $-0.377 * * *$ & $-0.377 * * *$ \\
\hline & & & {$[0.081]$} & {$[0.081]$} & {$[0.078]$} & {$[0.101]$} \\
\hline \multirow{2}{*}{$\begin{array}{l}\text { Stock Market Liberalization } \\
\text { Edison and Warnock (2003) Measure } \text { c,t }\end{array}$} & & & & 0.046 & & \\
\hline & & & & {$[0.038]$} & & \\
\hline \multirow[t]{2}{*}{ Log of GDP per capita ${ }_{c, t}$} & & & & & $0.101 * *$ & $0.101 * *$ \\
\hline & & & & & {$[0.044]$} & {$[0.043]$} \\
\hline \multirow[t]{2}{*}{ Market Capitalization / GDP ${ }_{c, t}$} & & & & & $0.114 * * *$ & $0.114 * * *$ \\
\hline & & & & & [0.032] & {$[0.028]$} \\
\hline \multirow{2}{*}{$\begin{array}{l}\text { Country Dummies } \\
\text { Year Dummies }\end{array}$} & Yes & Yes & Yes & Yes & Yes & Yes \\
\hline & Yes & Yes & Yes & Yes & Yes & Yes \\
\hline \multirow{4}{*}{$\begin{array}{l}\text { Number of Observations } \\
\text { Number of Firms } \\
\text { Number of Countries } \\
\text { R-squared }\end{array}$} & 705 & 663 & 653 & 660 & 653 & 653 \\
\hline & 120 & 107 & 106 & 110 & 106 & 106 \\
\hline & 20 & 18 & 18 & 18 & 18 & 18 \\
\hline & 0.54 & 0.55 & 0.57 & 0.56 & 0.57 & 0.57 \\
\hline
\end{tabular}




\section{Table V}

\section{Trading Activity of Domestic Firms}

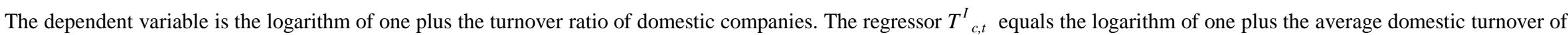

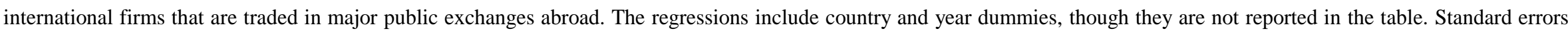

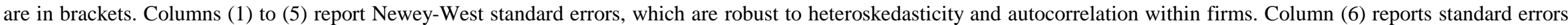
adjusted for clustering at the firm-level. *,**,*** mean significance at ten, five, and one percent, respectively. The estimated equation is the following:

$$
T_{j, c, t}^{D}=\phi \times A_{j, c, t}+\beta \times T_{c, t}^{I}+\gamma \times S T_{c, t}^{I}+\theta \times C_{c, t}+\delta_{1} \times n_{c}+\delta_{2} \times \tau_{t}+\varepsilon_{j, c, t}
$$

\begin{tabular}{|c|c|c|c|c|c|c|}
\hline \multicolumn{7}{|c|}{$\begin{array}{c}\text { Dependent Variable: } \\
\text { Log (1+Domestic Turnover })\end{array}$} \\
\hline & $(1)$ & (2) & (3) & $(4)$ & $(5)$ & $(6)$ \\
\hline Log of Total Assets ${ }_{\mathrm{j}, \mathrm{c}, \mathrm{t}}$ & $\begin{array}{l}-0.074 * * * \\
{[0.004]}\end{array}$ & $\begin{array}{l}-0.072 * * * \\
{[0.004]}\end{array}$ & $\begin{array}{l}-0.072 * * * \\
{[0.004]}\end{array}$ & $\begin{array}{l}-0.077 * * * \\
{[0.005]}\end{array}$ & $\begin{array}{l}-0.072 * * * \\
{[0.004]}\end{array}$ & $\begin{array}{l}-0.072 * * * \\
{[0.007]}\end{array}$ \\
\hline $\begin{array}{l}\text { Log }(1+\text { Average Turnover of Public International } \\
\text { Firms in the Domestic Market })_{c, t}\end{array}$ & $\begin{array}{l}0.500 * * * \\
{[0.033]}\end{array}$ & $\begin{array}{l}0.580 * * * \\
{[0.035]}\end{array}$ & $\begin{array}{l}0.567 * * * \\
{[0.038]}\end{array}$ & $\begin{array}{l}0.438 * * * \\
{[0.039]}\end{array}$ & $\begin{array}{l}0.596 * * * \\
{[0.038]}\end{array}$ & $\begin{array}{l}0.596 * * * \\
{[0.038]}\end{array}$ \\
\hline Stock Market Liberalization Dummy $y_{c, t}$ & & $\begin{array}{r}-0.022 \\
{[0.027]}\end{array}$ & $\begin{array}{r}-0.005 \\
{[0.025]}\end{array}$ & & $\begin{array}{r}-0.004 \\
{[0.026]}\end{array}$ & $\begin{array}{r}-0.004 \\
{[0.026]}\end{array}$ \\
\hline Log of $(1+\text { Value Traded Abroad/Total Value Traded })_{c, t}$ & & & $\begin{array}{l}-0.466 * * * \\
{[0.063]}\end{array}$ & $\begin{array}{l}-0.526 * * * \\
{[0.066]}\end{array}$ & $\begin{array}{l}-0.497 * * * \\
{[0.065]}\end{array}$ & $\begin{array}{l}-0.497 * * * \\
{[0.068]}\end{array}$ \\
\hline $\begin{array}{l}\text { Stock Market Liberalization } \\
\text { Edison and Warnock (2003) Measure }{ }_{c, t}\end{array}$ & & & & $\begin{array}{l}0.159 * * * \\
{[0.030]}\end{array}$ & & \\
\hline Log of GDP per capita ${ }_{c, t}$ & & & & & $\begin{array}{l}0.319 * * * \\
{[0.045]}\end{array}$ & $\begin{array}{l}0.319 * * * \\
{[0.043]}\end{array}$ \\
\hline Market Capitalization / GDP ${ }_{c, t}$ & & & & & $\begin{array}{l}-0.108 * * * \\
{[0.019]}\end{array}$ & $\begin{array}{l}-0.108 * * * \\
{[0.019]}\end{array}$ \\
\hline Country Dummies & Yes & Yes & Yes & Yes & Yes & Yes \\
\hline Year Dummies & Yes & Yes & Yes & Yes & Yes & Yes \\
\hline Number of Observations & 6,480 & 6,157 & 5,971 & 5,938 & 5,971 & 5,971 \\
\hline Number of Firms & 1,318 & 1,213 & 1,195 & 1,167 & 1,195 & 1,195 \\
\hline Number of Countries & 36 & 32 & 32 & 25 & 32 & 32 \\
\hline R-squared & 0.53 & 0.54 & 0.52 & 0.50 & 0.53 & 0.53 \\
\hline
\end{tabular}




\section{Table VI}

\section{Liquidity of Domestic Firms: Amihud Illiquidity Ratio}

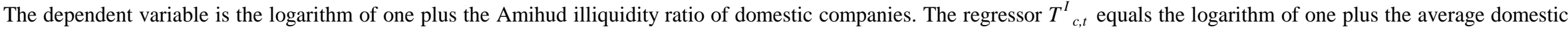

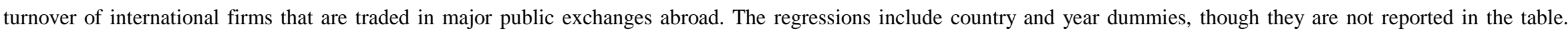

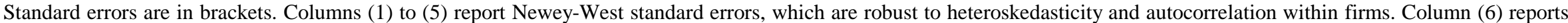
standard errors adjusted for clustering at the firm-level. *,**,** mean significance at ten, five, and one percent, respectively. The estimated equation is the following:

$$
I_{j, c, t}^{D}=\phi \times A_{j, c, t}+\beta \times T_{c, t}^{I}+\gamma \times S T_{c, t}^{I}+\theta \times C_{c, t}+\delta_{1} \times n_{c}+\delta_{2} \times \tau_{t}+\varepsilon_{j, c, t}
$$

\begin{tabular}{|c|c|c|c|c|c|c|}
\hline \multicolumn{7}{|c|}{$\begin{array}{c}\text { Dependent Variable: } \\
\text { Log (1+Amihud Illiquidity Ratio) }\end{array}$} \\
\hline & $(1)$ & $(2)$ & (3) & (4) & $(5)$ & (6) \\
\hline Log of Total Assets ${ }_{\mathrm{j}, \mathrm{c}, \mathrm{t}}$ & $\begin{array}{l}-0.097 * * * \\
{[0.004]}\end{array}$ & $\begin{array}{l}-0.096 * * * \\
{[0.004]}\end{array}$ & $\begin{array}{l}-0.098 * * * \\
{[0.004]}\end{array}$ & $\begin{array}{l}-0.100 * * * \\
{[0.004]}\end{array}$ & $\begin{array}{l}-0.095 * * * \\
{[0.004]}\end{array}$ & $\begin{array}{l}-0.095 * * * \\
{[0.007]}\end{array}$ \\
\hline $\begin{array}{l}\text { Log }(1+\text { Average Turnover of Public International } \\
\text { Firms in the Domestic Market })_{c, t}\end{array}$ & $\begin{array}{l}-0.179 * * * \\
{[0.023]}\end{array}$ & $\begin{array}{l}-0.220 * * * \\
{[0.024]}\end{array}$ & $\begin{array}{l}-0.267 * * * \\
{[0.032]}\end{array}$ & $\begin{array}{l}-0.168 * * * \\
{[0.032]}\end{array}$ & $\begin{array}{l}-0.180 * * * \\
{[0.032]}\end{array}$ & $\begin{array}{l}-0.180 * * * \\
{[0.033]}\end{array}$ \\
\hline Stock Market Liberalization Dummy ${ }_{c, t}$ & & $\begin{array}{r}0.046 \\
{[0.040]}\end{array}$ & $\begin{array}{r}0.031 \\
{[0.041]}\end{array}$ & & $\begin{array}{r}-0.066 \\
{[0.042]}\end{array}$ & $\begin{array}{r}-0.066 \\
{[0.051]}\end{array}$ \\
\hline Log of $(1+\text { Value Traded Abroad/Total Value Traded })_{c, t}$ & & & $\begin{array}{l}0.282 * * \\
{[0.116]}\end{array}$ & $\begin{array}{l}0.410 * * * \\
{[0.117]}\end{array}$ & $\begin{array}{l}0.440 * * * \\
{[0.117]}\end{array}$ & $\begin{array}{l}0.440 * * * \\
{[0.149]}\end{array}$ \\
\hline $\begin{array}{l}\text { Stock Market Liberalization } \\
\text { Edison and Warnock (2003) Measure } \text { ch,t }\end{array}$ & & & & $\begin{array}{l}-0.190 * * * \\
{[0.029]}\end{array}$ & & \\
\hline Log of GDP per capita ${ }_{c, t}$ & & & & & $\begin{array}{l}-0.184 * * * \\
{[0.053]}\end{array}$ & $\begin{array}{l}-0.184 * * * \\
{[0.059]}\end{array}$ \\
\hline Market Capitalization / GDP ${ }_{c, t}$ & & & & & $\begin{array}{l}-0.179 * * * \\
{[0.014]}\end{array}$ & $\begin{array}{l}-0.179 * * * \\
{[0.017]}\end{array}$ \\
\hline Country Dummies & Yes & Yes & Yes & Yes & Yes & Yes \\
\hline Year Dummies & Yes & Yes & Yes & Yes & Yes & Yes \\
\hline Number of Observations & 5,879 & 5,573 & 5,373 & 5,510 & 5,373 & 5,373 \\
\hline Number of Firms & 989 & 915 & 909 & 910 & 909 & 909 \\
\hline Number of Countries & 31 & 29 & 29 & 24 & 29 & 29 \\
\hline R-squared & 0.39 & 0.40 & 0.40 & 0.38 & 0.42 & 0.42 \\
\hline
\end{tabular}




\section{Table VII}

\section{Liquidity of Domestic Firms: Proportion of Zero Return Days}

The dependent variable is the logarithm of one plus the proportion of zero return days of domestic companies. The regressor $T_{c, t}^{I}$ equals the logarithm of one plus the average domestic turnover of international firms that are traded in major public exchanges abroad. The regressions include country and year dummies, though they are not reported in the table. Standard errors are in brackets. Columns (1) to (5) report Newey-West standard errors, which are robust to heteroskedasticity and autocorrelation within firms. Column (6) reports standard errors adjusted for clustering at the firm-level. $*, * *, * * *$ mean significance at ten, five, and one percent, respectively. The estimated equation is the following:

$$
Z R_{j, c, t}^{D}=\phi \times A_{j, c, t}+\beta \times T_{c, t}^{I}+\gamma \times S T_{c, t}^{I}+\theta \times C_{c, t}+\delta_{1} \times n_{c}+\delta_{2} \times \tau_{t}+\varepsilon_{j, c, t}
$$

\begin{tabular}{|c|c|c|c|c|c|c|}
\hline & $\begin{array}{r}\text { Dep } \\
\text { g }(1+\text { Propo }\end{array}$ & $\begin{array}{l}\text { nt Variabl } \\
\text { of Zero R }\end{array}$ & ( Days) & & & \\
\hline & (1) & (2) & (3) & (4) & (5) & (6) \\
\hline Log of Total Assets ${ }_{j, c, t}$ & $\begin{array}{l}-0.020 * * * \\
{[0.001]}\end{array}$ & $\begin{array}{l}-0.020 * * * \\
{[0.001]}\end{array}$ & $\begin{array}{l}-0.020 * * * \\
{[0.001]}\end{array}$ & $\begin{array}{l}-0.021 * * * \\
{[0.001]}\end{array}$ & $\begin{array}{l}-0.020 * * * \\
{[0.001]}\end{array}$ & $\begin{array}{l}-0.020 * * * \\
{[0.002]}\end{array}$ \\
\hline $\begin{array}{l}\text { Log }(1+\text { Average Turnover of Public International } \\
\text { Firms in the Domestic Market })_{c, t}\end{array}$ & $\begin{array}{l}-0.043 * * * \\
{[0.007]}\end{array}$ & $\begin{array}{l}-0.049 * * * \\
{[0.007]}\end{array}$ & $\begin{array}{l}-0.066 * * * \\
{[0.009]}\end{array}$ & $\begin{array}{l}-0.063 * * * \\
{[0.009]}\end{array}$ & $\begin{array}{l}-0.047 * * * \\
{[0.010]}\end{array}$ & $\begin{array}{l}-0.047 * * * \\
{[0.011]}\end{array}$ \\
\hline Stock Market Liberalization Dummy $\mathrm{c}_{\mathrm{c}, \mathrm{t}}$ & & $\begin{array}{r}0.006 \\
{[0.013]}\end{array}$ & $\begin{array}{r}-0.006 \\
{[0.012]}\end{array}$ & & $\begin{array}{l}-0.025 * * \\
{[0.012]}\end{array}$ & $\begin{array}{r}-0.025 \\
{[0.016]}\end{array}$ \\
\hline Log of $(1+\text { Value Traded Abroad/Total Value Traded })_{c, t}$ & & & $\begin{array}{l}0.277 * * * \\
{[0.039]}\end{array}$ & $\begin{array}{l}0.285 * * * \\
{[0.040]}\end{array}$ & $\begin{array}{l}0.303 * * * \\
{[0.040]}\end{array}$ & $\begin{array}{l}0.303 * * * \\
{[0.048]}\end{array}$ \\
\hline $\begin{array}{l}\text { Stock Market Liberalization } \\
\text { Edison and Warnock (2003) Measure } \text { M }, t\end{array}$ & & & & $\begin{array}{r}0.011 \\
{[0.008]}\end{array}$ & & \\
\hline Log of GDP per capita ${ }_{c, t}$ & & & & & $\begin{array}{r}0.000 \\
{[0.015]}\end{array}$ & $\begin{array}{r}0.000 \\
{[0.016]}\end{array}$ \\
\hline Market Capitalization / GDP ${ }_{c, t}$ & & & & & $\begin{array}{l}-0.045 * * * \\
{[0.004]}\end{array}$ & $\begin{array}{l}-0.045 * * * \\
{[0.004]}\end{array}$ \\
\hline Country Dummies & Yes & Yes & Yes & Yes & Yes & Yes \\
\hline Year Dummies & Yes & Yes & Yes & Yes & Yes & Yes \\
\hline Number of Observations & 6,380 & 6,067 & 5,863 & 5,999 & 5,863 & 5,863 \\
\hline Number of Firms & 1,025 & 950 & 944 & 946 & 944 & 944 \\
\hline Number of Countries & 31 & 29 & 29 & 24 & 29 & 29 \\
\hline R-squared & 0.49 & 0.51 & 0.51 & 0.48 & 0.52 & 0.52 \\
\hline
\end{tabular}


Appendix Table I

Basic Statistics and Means

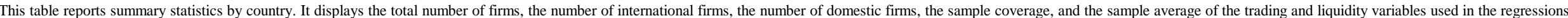
International companies are the ones that issue a depositary receipt, cross-list, or raise capital in international equity markets.

\begin{tabular}{|c|c|c|c|c|c|c|c|c|c|c|c|c|c|c|c|c|c|c|c|c|}
\hline & \multirow{3}{*}{ Country } & \multirow{2}{*}{\multicolumn{2}{|c|}{$\begin{array}{l}\text { No. of Firms in the } \\
\text { Regressions }\end{array}$}} & \multirow{2}{*}{\multicolumn{2}{|c|}{$\begin{array}{l}\text { No. of Firms in the } \\
\text { Aggregate Measures }\end{array}$}} & \multirow{2}{*}{\multicolumn{2}{|c|}{ Total No. of Firms }} & \multirow{3}{*}{ Sample Period } & \multicolumn{6}{|c|}{ Domestic Firms } & \multicolumn{6}{|c|}{ International Firms } \\
\hline & & & & & & & & & \multicolumn{2}{|c|}{$\begin{array}{c}\text { Turnover in } \\
\text { Domestic Market }\end{array}$} & \multicolumn{2}{|c|}{$\begin{array}{c}\text { Amihud Illiquidity } \\
\text { Ratio }\end{array}$} & \multicolumn{2}{|c|}{$\begin{array}{c}\text { Proportion of Zero } \\
\text { Return Days }\end{array}$} & \multicolumn{2}{|c|}{$\begin{array}{c}\text { Turnover in } \\
\text { Domestic Market }\end{array}$} & \multicolumn{2}{|c|}{$\begin{array}{c}\text { Turnover in } \\
\text { Domestic } \\
\text { Market/Total } \\
\text { Turnover } \\
\end{array}$} & \multicolumn{2}{|c|}{ Total Turnover } \\
\hline & & $\begin{array}{c}\text { Int'l. } \\
\text { Firms } \\
\end{array}$ & $\begin{array}{l}\text { Dom. } \\
\text { Firms } \\
\end{array}$ & $\begin{array}{c}\text { Int'l. } \\
\text { Firms }\end{array}$ & $\begin{array}{c}\text { Dom. } \\
\text { Firms } \\
\end{array}$ & $\begin{array}{c}\text { Int'l. } \\
\text { Firms }\end{array}$ & $\begin{array}{c}\text { Dom. } \\
\text { Firms } \\
\end{array}$ & & Mean & Std. Dev. & Mean & Std. Dev. & Mean & Std. Dev. & Mean & Std. Dev. & Mean & Std. Dev. & Mean & Std. Dev. \\
\hline 1 & Argentina & 8 & 9 & 18 & 9 & 22 & 10 & $1990-2000$ & 0.40 & 0.29 & 1.67 & 1.57 & 0.48 & 0.26 & 0.27 & 0.27 & 0.44 & 0.40 & 0.45 & 0.31 \\
\hline 2 & Bahrain & 1 & 14 & 1 & 12 & 1 & 14 & 1999-2000 & 0.11 & 0.13 & & & & & 0.05 & & & & & \\
\hline 3 & Brazil & 49 & 47 & 29 & 52 & 52 & 52 & $1989-2000$ & 0.33 & 0.39 & 0.61 & 1.30 & 0.40 & 0.27 & 0.41 & 0.38 & 0.78 & 0.30 & 0.47 & 0.45 \\
\hline 4 & Bulgaria & 1 & 0 & 0 & 16 & 1 & 16 & $1998-2000$ & & & & & & & 0.03 & 0.02 & & & & \\
\hline 5 & Chile & 21 & 33 & 22 & 36 & 24 & 36 & 1989-2000 & 0.09 & 0.10 & 1.12 & 0.88 & 0.50 & 0.25 & 0.13 & 0.11 & 0.45 & 0.32 & 0.42 & 0.31 \\
\hline 6 & China & 50 & 78 & 27 & 200 & 54 & 200 & 1992-2000 & 1.59 & 1.97 & 0.75 & 0.80 & 0.41 & 0.26 & 1.40 & 1.47 & 0.74 & 0.23 & 2.15 & 1.38 \\
\hline 7 & Colombia & 7 & 21 & 3 & 28 & 7 & 28 & 1989-2000 & 0.10 & 0.08 & 1.31 & 1.00 & 0.63 & 0.24 & 0.12 & 0.08 & . & . & . & . \\
\hline 8 & Croatia & 2 & 5 & 1 & 7 & 2 & 7 & 1997-2000 & 0.04 & 0.05 & & & & & 0.04 & 0.04 & . & . & . & . \\
\hline 9 & Czech Republic & 5 & 45 & 3 & 71 & 5 & 71 & 1995-2000 & 0.21 & 0.49 & 3.08 & 2.60 & 0.37 & 0.21 & 0.40 & 0.42 & . & . & . & . \\
\hline 10 & Egypt & 6 & 14 & 7 & 72 & 7 & 72 & $1997-2000$ & 0.30 & 0.41 & 1.18 & 1.30 & 0.20 & 0.15 & 0.41 & 0.29 & . & . & . & . \\
\hline 11 & Estonia & 2 & 8 & 1 & 11 & 2 & 11 & $1997-2000$ & 0.26 & 0.29 & 2.55 & 2.10 & 0.47 & 0.25 & 0.30 & 0.47 & & & & \\
\hline 12 & Ghana & 1 & 10 & 1 & 10 & 1 & 10 & 1996-2000 & 0.09 & 0.12 & & & & & 0.00 & 0.00 & 0.00 & 0.00 & 0.49 & 0.18 \\
\hline 13 & Greece & 8 & 67 & 9 & 77 & 11 & 77 & 1989-2000 & 0.60 & 0.55 & 1.02 & 1.71 & 0.23 & 0.20 & 0.41 & 0.39 & 0.98 & 0.05 & 0.35 & 0.25 \\
\hline 14 & Hungary & 15 & 8 & 9 & 10 & 15 & 10 & 1992-2000 & 0.65 & 0.50 & 1.21 & 1.63 & 0.28 & 0.26 & 0.86 & 1.20 & 0.75 & 0.16 & 0.47 & 0.33 \\
\hline 15 & India & 49 & 108 & 28 & 130 & 52 & 130 & $1990-2000$ & 0.34 & 1.02 & 2.07 & 2.11 & 0.23 & 0.15 & 0.62 & 1.10 & 0.90 & 0.15 & 1.14 & 1.83 \\
\hline 16 & Indonesia & 8 & 97 & 5 & 129 & 10 & 129 & $1990-2000$ & 0.96 & 1.67 & 1.00 & 1.30 & 0.55 & 0.22 & 0.49 & 0.38 & 0.50 & 0.19 & 0.68 & 0.25 \\
\hline 17 & Israel & 18 & 28 & 17 & 34 & 20 & 34 & $1997-2000$ & 0.26 & 0.14 & 0.27 & 0.33 & 0.15 & 0.06 & 0.45 & 0.33 & 0.58 & 0.33 & 0.74 & 0.46 \\
\hline 18 & Jamaica & 2 & 0 & 0 & 17 & 2 & 17 & 1999-2000 & & & ${ }^{\prime}$ & & . & & 0.07 & 0.06 & . & . & . & 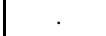 \\
\hline 19 & Jordan & 3 & 4 & 1 & 41 & 3 & 41 & 1997-2000 & 0.13 & 0.08 & & & & & 0.07 & 0.05 & & & & \\
\hline 20 & Korea & 32 & 176 & 18 & 195 & 33 & 196 & 1989-2000 & 3.87 & 6.75 & 0.24 & 0.59 & 0.17 & 0.06 & 2.25 & 4.22 & 0.88 & 0.15 & 1.57 & 3.85 \\
\hline 21 & Latvia & 2 & 12 & 2 & 14 & 2 & 14 & $1997-2000$ & 0.45 & 0.71 & 4.12 & 1.23 & 0.47 & 0.19 & 0.40 & 0.40 & . & . & . & . \\
\hline 22 & Lebanon & 2 & 0 & 0 & 3 & 2 & 3 & $1999-2000$ & & & & & & & 0.08 & 0.11 & . & . & . & . \\
\hline 23 & Lithuania & 4 & 8 & 1 & 40 & 4 & 40 & 1996-2000 & 0.11 & 0.18 & 3.64 & 2.06 & 0.66 & 0.21 & 0.23 & 0.26 & & & & \\
\hline
\end{tabular}




\section{Appendix Table I (Continued)}

Basic Statistics and Means

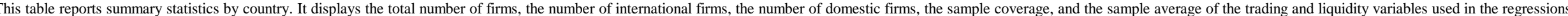
International companies are the ones that issue a depositary receipt, cross-list, or raise capital in international equity markets.

\begin{tabular}{|c|c|c|c|c|c|c|c|c|c|c|c|c|c|c|c|c|c|c|c|c|}
\hline & \multirow{3}{*}{ Country } & \multirow{2}{*}{\multicolumn{2}{|c|}{$\begin{array}{l}\text { No. of Firms in the } \\
\text { Regressions }\end{array}$}} & \multirow{2}{*}{\multicolumn{2}{|c|}{$\begin{array}{l}\text { No. of Firms in the } \\
\text { Aggregate Measures }\end{array}$}} & \multirow{2}{*}{\multicolumn{2}{|c|}{ Total No. of Firms }} & \multirow{3}{*}{ Sample Period } & \multicolumn{6}{|c|}{ Domestic Firms } & \multicolumn{6}{|c|}{ International Firms } \\
\hline & & & & & & & & & \multicolumn{2}{|c|}{$\begin{array}{c}\text { Turnover in } \\
\text { Domestic Market }\end{array}$} & \multicolumn{2}{|c|}{$\begin{array}{c}\text { Amihud Illiquidity } \\
\text { Ratio }\end{array}$} & \multicolumn{2}{|c|}{$\begin{array}{c}\text { Proportion of Zero } \\
\text { Return Days }\end{array}$} & \multicolumn{2}{|c|}{$\begin{array}{c}\text { Turnover in } \\
\text { Domestic Market }\end{array}$} & \multicolumn{2}{|c|}{$\begin{array}{c}\text { Turnover in } \\
\text { Domestic } \\
\text { Market/Total } \\
\text { Turnover } \\
\end{array}$} & \multicolumn{2}{|c|}{ Total Turnover } \\
\hline & & $\begin{array}{c}\text { Int'l. } \\
\text { Firms } \\
\end{array}$ & $\begin{array}{l}\text { Dom. } \\
\text { Firms } \\
\end{array}$ & $\begin{array}{c}\text { Int'l. } \\
\text { Firms }\end{array}$ & $\begin{array}{c}\text { Dom. } \\
\text { Firms } \\
\end{array}$ & $\begin{array}{c}\text { Int'l. } \\
\text { Firms } \\
\end{array}$ & $\begin{array}{c}\text { Dom. } \\
\text { Firms } \\
\end{array}$ & & Mean & Std. Dev. & Mean & Std. Dev. & Mean & Std. Dev. & Mean & Std. Dev. & Mean & Std. Dev. & Mean & Std. Dev. \\
\hline 24 & Malaysia & 13 & 174 & 3 & 183 & 13 & 188 & 1989-2000 & 1.29 & 4.24 & 0.57 & 0.85 & 0.25 & 0.10 & 0.30 & 0.41 & & & & \\
\hline 25 & Mexico & 51 & 13 & 41 & 38 & 61 & 38 & 1989-2000 & 0.32 & 0.32 & 0.26 & 0.48 & 0.27 & 0.18 & 0.46 & 0.38 & 0.52 & 0.33 & 1.17 & 0.91 \\
\hline 26 & Morocco & 1 & 11 & 1 & 20 & 1 & 20 & 1997-2000 & 0.11 & 0.07 & 0.09 & 0.05 & 0.33 & 0.11 & 0.21 & 0.11 & . & 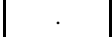 & . & 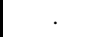 \\
\hline 27 & Nigeria & 1 & 0 & 0 & 27 & 1 & 27 & 1999-2000 & . & & . & . & 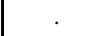 & & 0.05 & 0.03 & . & 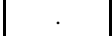 & 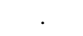 & . \\
\hline 28 & Pakistan & 4 & 0 & 0 & 56 & 4 & 56 & 1997-2000 & & & & & & & 3.32 & 3.17 & & & & \\
\hline 29 & Peru & 8 & 22 & 5 & 34 & 8 & 34 & 1992-2000 & 0.75 & 0.70 & 1.33 & 1.10 & 0.51 & 0.25 & 0.32 & 0.28 & 0.60 & 0.30 & 0.49 & 0.35 \\
\hline 30 & Philippines & 15 & 58 & 6 & 63 & 16 & 63 & $1989-2000$ & 0.71 & 1.06 & 1.41 & 1.52 & 0.46 & 0.22 & 0.28 & 0.23 & 0.69 & 0.30 & 0.62 & 0.45 \\
\hline 31 & Poland & 17 & 23 & 8 & 27 & 18 & 27 & $1992-2000$ & 0.78 & 0.75 & 1.21 & 1.21 & 0.27 & 0.21 & 0.77 & 0.88 & & & & \\
\hline 32 & Portugal & 8 & 28 & 3 & 39 & 8 & 39 & 1989-1998 & 0.27 & 0.21 & 1.19 & 1.26 & 0.43 & 0.20 & 0.61 & 0.52 & 0.84 & 0.16 & 0.53 & 0.43 \\
\hline 33 & Romania & 1 & 12 & 1 & 32 & 1 & 34 & 1999-2000 & 0.24 & 0.18 & 1.26 & 1.43 & 0.75 & 0.21 & 0.05 & & & & & \\
\hline 34 & Russia & 14 & 11 & 5 & 23 & 16 & 23 & 1996-2000 & 0.28 & 0.37 & 1.67 & 1.49 & 0.69 & 0.26 & 0.33 & 0.48 & 0.63 & 0.30 & 0.88 & 0.84 \\
\hline 35 & Slovak Republic & 2 & 0 & 0 & 18 & 2 & 18 & 1997-2000 & & & & & & & 0.21 & 0.27 & & . & & . \\
\hline 36 & Slovenia & 2 & 14 & 2 & 15 & 2 & 16 & 1996-2000 & 0.34 & 0.30 & 0.52 & 0.87 & 0.14 & 0.10 & 0.39 & 0.22 & & & & \\
\hline 37 & South Africa & 46 & 37 & 25 & 41 & 48 & 41 & 1992-2000 & 0.22 & 0.32 & 0.44 & 0.65 & 0.37 & 0.25 & 0.23 & 0.28 & 0.91 & 0.24 & 0.46 & 0.35 \\
\hline 38 & Sri Lanka & 1 & 0 & 0 & 65 & 1 & 65 & 1994-2000 & & & & & & & 0.24 & 0.08 & & & & \\
\hline 39 & Taiwan & 29 & 115 & 13 & 113 & 29 & 118 & $1989-2000$ & 3.85 & 3.69 & 0.04 & 0.10 & 0.17 & 0.04 & 3.15 & 3.36 & 0.96 & 0.08 & 4.06 & 3.13 \\
\hline 40 & Thailand & 13 & 0 & 0 & 112 & 13 & 112 & 1989-2000 & & & . & & . & & 0.65 & 0.87 & & . & . & \\
\hline 41 & Tunisia & 1 & 11 & 1 & 17 & 1 & 17 & 1996-2000 & 0.09 & 0.08 & & & & & 0.15 & 0.07 & & . & & . \\
\hline 42 & Turkey & 13 & 55 & 6 & 64 & 14 & 64 & 1990-2000 & 2.09 & 3.21 & 0.30 & 0.52 & 0.42 & 0.26 & 1.98 & 4.10 & 0.64 & . & 0.38 & . \\
\hline 43 & Ukraine & 4 & 0 & 0 & 14 & 4 & 14 & 1997-2000 & & & & & & & 0.16 & 0.14 & & & & \\
\hline 44 & Venezuela & 13 & 7 & 4 & 10 & 13 & 10 & 1989-2000 & 0.13 & 0.10 & 0.78 & 0.64 & 0.52 & 0.30 & 0.32 & 0.34 & 0.49 & 0.39 & 0.63 & 0.71 \\
\hline \multirow[t]{2}{*}{45} & Zimbabwe & 4 & 8 & 3 & 21 & 4 & 23 & 1993-2000 & 0.13 & 0.12 & 1.21 & 0.78 & 0.56 & 0.14 & 0.22 & 0.18 & 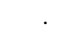 & . & . & . \\
\hline & Total & 557 & 1,391 & 330 & 2,246 & 610 & 2,265 & & 1.51 & 3.73 & 0.79 & 1.31 & 0.31 & 0.22 & 0.79 & 1.85 & 0.63 & 0.34 & 0.89 & 1.43 \\
\hline
\end{tabular}




\section{Appendix Table II}

\section{Series Description and Data Sources}

This table shows the description of the data used and their coverage and sources.

\begin{tabular}{|c|c|c|}
\hline Series & Description & Source \\
\hline $\begin{array}{l}\text { Variables related to the } \\
\text { internationalization of stock } \\
\text { markets }\end{array}$ & $\begin{array}{l}\text { Dates of cross-listings, depositary receipts issuances, and capital raisings in international equity } \\
\text { markets. This information is used to classify firms as domestic or international and date the start of } \\
\text { their international activities. International companies are the ones that issue a depositary receipt, cross- } \\
\text { list, or raise capital in international equity markets. Different variables are constructed using these } \\
\text { data. See text for details. }\end{array}$ & $\begin{array}{l}\text { Bank of New York, Citigroup, Euromoney, JP Morgan, the London Stock } \\
\text { Exchange (LSE), the New York Stock Exchange (NYSE), and NASDAQ }\end{array}$ \\
\hline Domestic market capitalization & Market capitalization in domestic stock markets. End-of-year data in current U.S. dollars. & $\begin{array}{l}\text { Standard \& Poor's Emerging Markets Database (formerly collected by the } \\
\text { International Finance Corporation, IFC) }\end{array}$ \\
\hline Domestic value traded & Value traded in domestic stock markets. Annual data in current U.S. dollars. & $\begin{array}{l}\text { Standard \& Poor's Emerging Markets Database (formerly collected by the } \\
\text { International Finance Corporation, IFC) }\end{array}$ \\
\hline Value traded abroad & $\begin{array}{l}\text { Value traded in American Depositary Receipts covering the period 1989-2000. The series are } \\
\text { computed at the firm level by adding the different depositary receipts that belong to each company on } \\
\text { a yearly basis. Data are in current U.S. dollars. }\end{array}$ & Bank of New York \\
\hline GDP per capita at market prices & $\begin{array}{l}\text { Gross domestic product (GDP) in current U.S. dollars divided by mid-year population. The GDP (at } \\
\text { purchaser prices data) is converted from domestic currencies using official exchange rates. For the } \\
\text { cases in which the official exchange rate is different from the market rate, the latter is used. }\end{array}$ & World Bank: World Development Indicators \\
\hline $\begin{array}{l}\text { Stock market liberalization } \\
\text { dummy }\end{array}$ & $\begin{array}{l}\text { Dummy that equals one on and after the year of stock market liberalization. The liberalization date } \\
\text { corresponds to the date of formal regulatory change after which foreign investors officially have the } \\
\text { possibility to invest in domestic equity securities. For the data from Vinhas de Souza (2005), we } \\
\text { consider the first year when a country's stock market is fully liberalized as the liberalization date. }\end{array}$ & Bekaert, Harvey, and Lundbald (2005) and Vinhas de Souza (2005) \\
\hline $\begin{array}{l}\text { Stock Market Liberalization } \\
\text { Edison and Warnock (2003) } \\
\text { Measure }\end{array}$ & $\begin{array}{l}\text { Stock market liberalization measure based on S\&P/IFC Indexes. The variable used is the smoothed } \\
\text { measure calculated by Edison and Warnock }(2003) \text {, which takes into account asymmetric shocks to } \\
\text { investable and non-investable stocks. We converted their capital control index into a liberalization } \\
\text { measure by subtracting one from it. }\end{array}$ & Edison and Warnock (2003) \\
\hline Total assets & $\begin{array}{l}\text { Total assets as reported in Worldscope for each firm-year, in millions of U.S. dollars. The sample } \\
\text { covers the period 1989-2000 for all countries. }\end{array}$ & Worldscope \\
\hline Daily stock price & $\begin{array}{l}\text { Daily stock price in domestic markets (main stock exchange). Data in current U.S. dollars are used to } \\
\text { calculated the Amihud illiquidity ratio, so the data are comparable across countries. Similar results are } \\
\text { obtained when calculating the Amihud illiquidity ratio using data in local currency. Data in local } \\
\text { currency are used to calculate the proportion of zero-return days. }\end{array}$ & Datastream \\
\hline Daily volume traded & $\begin{array}{l}\text { Daily number of shares traded in domestic markets (main stock exchange). Used to calculate Amihud } \\
\text { illiquidity ratio. }\end{array}$ & Datastream \\
\hline
\end{tabular}

